NBER WORKING PAPER SERIES

LESSONS FOR PUBLIC PENSIONS FROM UTAH'S MOVE TO PENSION CHOICE

\author{
Robert L. Clark \\ Emma Hanson \\ Olivia S. Mitchell \\ Working Paper 21385 \\ http://www.nber.org/papers/w21385
NATIONAL BUREAU OF ECONOMIC RESEARCH
1050 Massachusetts Avenue
Cambridge, MA 02138
July 2015

The research described in this paper began with a conversation with Richard Ellis, State Treasurer of Utah, who provided introductions to the leaders of the Utah Retirement System (URS) and supported our examination of the impact of pension reform in Utah. The authors acknowledge the assistance of Daniel Anderson, Executive Director; Jeff Allen, Chief Information Officer; John Brinkerhoff, Chief Privacy Officer and Information Security Officer; Joe Kanis, Retirement Applications Manager; and others at URS. This work was presented at "Retirement and Health Benefit in the Public Sector," an NBER conference, and useful comments were provided by David Laibson. Research support was provided by the Pension Research Council/Boettner Center at The Wharton School of the University of Pennsylvania. The research is part of the NBER programs on Aging, Public Economics, and Labor Studies. Opinions and errors are solely those of the authors and not of the institutions with whom the authors are affiliated, nor of the National Bureau of Economic Research.

At least one co-author has disclosed a financial relationship of potential relevance for this research. Further information is available online at http://www.nber.org/papers/w21385.ack

NBER working papers are circulated for discussion and comment purposes. They have not been peerreviewed or been subject to the review by the NBER Board of Directors that accompanies official NBER publications.

(C) 2015 by Robert L. Clark, Emma Hanson, and Olivia S. Mitchell. All rights reserved. Short sections of text, not to exceed two paragraphs, may be quoted without explicit permission provided that full credit, including $\odot$ notice, is given to the source. 
Lessons for Public Pensions from Utah's Move to Pension Choice

Robert L. Clark, Emma Hanson, and Olivia S. Mitchell

NBER Working Paper No. 21385

July 2015

JEL No. H55,H75,J26,J38

\begin{abstract}
We explore what happened when the state of Utah moved away from its traditional defined benefit pension. In its place, it offered new hires a choice between a conventional defined contribution plan and a hybrid plan option, where the latter has both a guaranteed benefit component and a defined contribution plan where employees bear investment risk. We show that around 60 percent of new hires failed to make any active choice and, as a result, were automatically defaulted into the hybrid plan. Slightly more than half of those who made an active choice elected the hybrid plan. Post-reform, employees who failed to actively elect a primary retirement plan were also far less likely to enroll in a supplemental retirement account, compared to new hires who actively selected a plan. We also find that employees hired following the reform were more likely to leave public employment, resulting in higher separation rates. This could reflect a reduction in the desirability of public employment under the new pension design and an improving economic climate in the state. Our results imply that public pension reformers must consider employee responses in addition to potential cost savings, when developing and enacting major pension plan changes.
\end{abstract}

\author{
Robert L. Clark \\ Poole College of Management \\ Box 7229 \\ North Carolina State University \\ Raleigh, NC 27695 \\ and NBER \\ robert_clark@ncsu.edu \\ Emma Hanson \\ North Carolina Department of State Treasurer \\ Retirement Systems Division \\ 3200 Atlantic Avenue \\ Raleigh, NC 27604 \\ and North Carolina State University \\ Emma.Hanson@nctreasurer.com
}

Olivia S. Mitchell

University of Pennsylvania

The Wharton School

3620 Locust Walk, St 3000 SH-DH

Philadelphia, PA 19104-6302

and NBER

mitchelo@wharton.upenn.edu 


\title{
Lessons for Public Pensions from Utah's Move to Pension Choice
}

\author{
Robert L. Clark, Emma Hanson, and Olivia S. Mitchell
}

The financial crisis of 2008-09 took a major toll on U.S. public pension plan investments, and the ensuing Great Recession deepened the challenges facing these plans. As a consequence, many public employers were forced to restructure their retirement schemes, and a recent survey found that since 2011, almost all states changed public pension benefit and contribution formulas to rein in costs (NASRA, 2014a). Moreover, several states have taken a further step, significantly modifying their plan designs so as to transfer risk from plan sponsors to employees. In particular, several states have offered employees the option to choose which retirement plan they want, with options including defined benefit, defined contribution, and hybrid plans.

This paper explores the restructuring of Utah's statewide public employee pension system in 2011, in response to the financial challenges described above. Previously, the Utah Retirement System (URS) provided public employees with a traditional defined benefit (DB) plan. Before the 2008-09 financial downturn, Utah's pension system was one of the best-funded statewide pension plans in the country, with an average funded ratio of 95 percent. With the downturn, however, investments losses led to in a substantial decline in URS's funded ratio which dropped to 83 percent by 2010. ${ }^{1}$ Consequently, the system's actuaries forecasted that large increases in annual required contributions would be needed to cover the losses. To avoid imposing additional financial strain on taxpayers, the Utah legislature responded by proposing

\footnotetext{
${ }^{1}$ URS's funded ratio as of January 1, 2013 was 77.1 percent. This includes the recognition of the final 20 percent of the 2008 investment loss.
} 
major changes to pension offerings provided to new employees. ${ }^{2}$ Public employees protested these pension reforms and urged lawmakers to "proceed with caution" (Dallof 2010). The legislator sponsoring the reform, Dan Liljenquist, explained that the goals of the "reform were two-fold: one, to make sure that we could meet every penny of the commitment that we had already made to current employees and retirees, and two, to reduce and eventually eliminate the pension-related bankruptcy risk to the state" (cited in McGuinn 2015: 9). ${ }^{3}$

Legislation authorizing the pension reform passed in March 2010 and went into effect in July 2011, officially closing the defined benefit (DB) plans to new employees and establishing the two-option replacement plan. ${ }^{4}$ The two new pension options were expected to be less generous than the former DB plans and could, therefore, be anticipated to reduce the state's future pension liabilities. Post-reform, new hires could choose one of two new options: a defined contribution (DC) plan, or a hybrid pension plan that incorporated both DB and DC elements (about which we say more below). New hires who failed to make an active choice between plans were automatically enrolled in the hybrid plan after one year of employment.

Using administrative data provided by URS, we examine how new hires' plan choices differed according to individual and job characteristics. Additionally, we evaluate how the pension reform changed two employee behaviors: contributions to supplemental plans, and turnover patterns. Prior literature has not examined these behavioral responses to public

\footnotetext{
${ }^{2}$ Due to legal constraints, benefits could not be reduced for existing employees.

${ }^{3}$ A simulation analysis by Evans and Phillips (2014) estimated that the pre-reform Utah retirement system had a 50 percent chance of exhausting its pension fund by 2028 .

${ }^{4}$ This legislation passed the Senate 19-9 and the House 46-26. Amendments made in the House increased the employer cost and the generosity of the new plan. The bill's history and related documents are available at http://le.utah.gov/ 2010/bills/static/SB0063.html.
} 
pension changes, focusing instead on differences in funding, contributions, and benefits. ${ }^{5}$ By contrast, our analysis provides evidence from Utah suggesting that it is important not to neglect the effects of retirement plan restructuring on other public employee behavior. Indeed, such outcomes could undermine state governments' ability to deliver services promised to their citizens.

We summarize our findings in Figure 1. First, most new hires failed to make an active choice between the available pension plan options, so the default plan assignment mattered. Second, one might have anticipated that the less generous retirement plan would have encouraged new hires to save more through supplemental plans, but this did not occur. Interestingly, those who did actively elect their primary account were also likely to participate in supplemental retirement plans. Third, post-reform, public employee two-year separation rates rose 30 percent, from 13 to 17 percentage points, although this increase might have been a response to the improving economy.

\section{Figure 1 here}

In what follows, we begin by reviewing key aspects of Utah's traditional DB plan and compare it to the two new plans adopted in 2011. Using administrative records provided by URS, we then estimate models of plan choice to evaluate who elected which plan and who defaulted. Inasmuch as both of the new plans are likely to pay less generous retirement benefits than the prior DB pension, we also inquire whether new hires saved more voluntarily to bolster

\footnotetext{
${ }^{5}$ Plan sponsors generally are aware of the balancing act between two competing goals of providing adequate retirement income to members and ensuring the long-term financial stability of the plan. In the 2013 Summary Report to Members, Daniel Andersen, the executive director of URS wrote: "while conditions for retirement benefits have changed over the past few years, our primary purpose was to provide retirement security and professional service to members and retirees." (http://www.urs.org/mango/pdf/urs/SummaryReport/2013/summaryReport.pdf.)
} 
their retirement incomes. Additionally we compare turnover rates for both pre- and post-reform new hires, to assess the impact of retirement plan type on employee retention rates. In a final section, we draw lessons from the Utah reform relevant to other states and municipalities looking to restructure their pension offerings.

\section{Relevant Prior Studies}

While we lack the space to review the large literature on pensions and their effect on employee behavior, we call attention here to a few recent accounts of how public pensions have sought to deal with pressing fiscal challenges. Media reports by Walsh (2011), Lyman and Walsh (2014), and Greenhouse (2011), among others, have reported on changes in public pension benefit and contribution parameters in the wake of the financial and economic crisis. In the academic literature, Chingos and West (2013), Lachance, Mitchell, and Smetters (2003), and Milevsky, Promislow, and David (2004) examined specific state pension reforms and their impacts on funding and costs. ${ }^{6}$ More recently, Novy-Marx and Rauh (2015) have suggested that linking public pension payouts to investment performance could alleviate the critical funding shortfalls many states now face.

Particularly pertinent to the present paper is prior research on how pension reforms alter employee behavior. To date, however, most empirical studies have focused on private-sector firms and employees, as shown in two reviews by Gustman and Mitchell (1992), and Gustman, Mitchell, and Steinmeier (1994), and case studies of corporate plan conversions are discussed by Clark and Munzenmaier (2001). Yet relatively few private sector firms give employees the

\footnotetext{
${ }^{6}$ For useful historical treatments of US public pensions, see Clark, Craig, and Anhmed (2009), and Clark, Craig, and Wilson (2003). Mitchell (2012) and Pew Center on the States (2010a, b) review the financial challenges confronting modern-day public plans.
} 
opportunity to choose among alternative types of pension plans. ${ }^{7}$ For this reason, prior studies have mainly focused on how pensions affect worker turnover patterns, and they have provided two main findings. First, employees of firms offering pension plans tend to separate less frequently than employees at other firms (Allen, Clark, and McDermed, 1993). Whether this is causal or simply correlational has been difficult to confirm. Second, there appear to be no major differences in turnover rates between employees offered DB versus DC plans (Gustman and Steinmeier, 1995). This is contrary to what might be expected, since DB plans tend to be more "back-loaded" - meaning that employees with long tenures receive more valuable retirement benefits than short-tenure employees. By contrast, hybrid and DC plans provide more balanced benefits, rewarding employees more equitably with additional years of service. Moreover, retirement wealth accumulated in DC plans is more portable than that accumulated in traditional DB pensions, meaning that DC plans provide greater value than do DB plans to short-term workers who may wish to move to a new employer prior to retirement.

In the public sector, it is somewhat more common to give participants a choice between two or more retirement plans, particularly at public universities. For instance, NASRA (2010) noted that nearly half of all state universities offered faculty choice between a DB and a DC plan. Clark and Hanson (2011) reported that five statewide retirement systems covering general public employees or teachers offered a DB/DC choice, two offered a choice between a DB and a hybrid, and one offered a choice between all three plans types. According to Munnell, Aubry, and Cafarelli (2014), states launching optional DC plans before the financial crisis did so because these gave workers the opportunity to manage their own money, particularly in rising equity

\footnotetext{
${ }^{7}$ Some non-profit firms do allow employees some choice concerning their retirement plan, including the firm examined by Mitchell, Utkus, and Yang (2007).
} 
markets. Post-financial crisis, Utah along with Michigan (2010), Rhode Island (2011), and Virginia (2012) have established statewide systems which include hybrid plans. ${ }^{8}$

In the last two decades, many researchers have explored the impact of public sector plan choices on aspects of employee behavior. For instance, Clark, Ghent, and McDermed (2006) studied public university faculty members' pension plan choices in North Carolina. ${ }^{9}$ As expected, they found that older individuals were more likely to select the DB option, whereas younger and, potentially, more mobile workers were more likely to select the DC plan. In their study of Oregon's Public Employees Retirement System, Chalmers, Johnston, and Reuter (2008) evaluated how different plan types influenced older individuals' retirement patterns, and they concluded that a substantial minority of employees did not adequately understand the plans' complex incentives. Goldhaber and Grout (2013) studied the pension plan preferences of Washington State public school teachers, and they found that, with the exception of age, observable teacher and job characteristics were not significant predictors of new hires' plan choices. Brown and Weisbenner (2014) examined employees' DB versus DC plan choices in the Illinois State University system, using an administrative dataset linked to a participant survey on plan and worker attributes. They concluded that those preferring the DC plan were predominately men, who also were less risk averse and more financially literate than employees electing other plan options.

Though prior studies have explored which types of workers elected different retirement plans when given a choice, they have not illuminated worker responses along other dimensions.

\footnotetext{
${ }^{8}$ Nine other states offer some type of hybrid plans, http://www.ncsl.org/research/fiscal-policy/statedefined-contribution-hybrid-retirement-plans.aspx\#3

${ }^{9}$ Also see Clark and Pitts' (1999) examination of faculty members' pension plan choice patterns at North Carolina State University.
} 
Accordingly, in what follows, we investigate the determinants of plan choice by public sector employees in Utah, along with associations between plan choice and measures of two important behavioral outcomes: post-reform contributions to supplemental plans, and post-reform employment turnover rates.

\section{Public Retirement Plans in Utah}

Utah's public employee pension plans date to the first half of the $20^{\text {th }}$ century with retirement plans introduced for school teachers and firefighters. A statewide teachers' retirement system was established in 1937, followed by the adoption of a plan for state officers and employees in 1947. After a series of modifications, these plans were consolidated in 1963 into the Utah Retirement Systems. ${ }^{10}$ Today, URS provides retirement benefits for more than 450 public employers including the State of Utah, local governments, school districts, and some employees in higher educational institutions. (Faculty and other exempt higher education employees are not members of URS.) Most public employees in Utah are also covered by Social Security. ${ }^{11}$

In this section, we describe the various retirement plans offered to public employees in Utah. We first discuss the pre-reform defined benefit plan that covered full time employees prior to 2011. Next we review the post-reform hybrid and defined contribution plans offered to new hires following these reforms and compare the generosity of the pre and post-reform pension plans. Finally, we describe URS supplemental retirement savings plans available to employees both pre and post-reform.

${ }^{10}$ A brief history of the development of public sector retirement plans in Utah is available at https://www.urs.org/mango/pdf/urs/Miscellaneous/miniHistory.pdf

${ }^{11}$ A brief overview of the plans currently offered to Utah public employees appears in Appendix Table 1. 
The Traditional Defined Benefit Plan (Tier I). Employees hired prior to July 1, 2011, were automatically enrolled into URS Tier I System, a traditional DB plan. The Tier I Retirement System was composed of six different plans: a Public Employees' Contributory Retirement Plan, a Noncontributory Retirement System, a Public Safety Retirement System, a Firefighters' System, a Governors' and Legislators' Retirement Plan, and a Judges' Retirement System. ${ }^{12}$

More than 85 percent of Tier I members belonged to the Public Employees' Noncontributory Retirement System, ${ }^{13}$ where the employer covered the entire cost of the benefits. At retirement, a worker's benefit amount under this DB plan was derived by calculating two percent of his average monthly earnings from his three highest years of earnings, multiplied by his years of service. Thus a 30-year career worker would have earned a lifetime income stream equal to 60 percent of his highest three years of earnings. After retirement, benefits were indexed by up to a 4 percent annual cost of living adjustment (NASRA 2014b). Retirement ages were defined by a combination of age and service: normal retirement benefits were payable at age 65 with 4 years of service, or 30 years of service at any age. Early retirees could begin benefits at age 60 with 20 years of service, age 62 with 10 years of service, or at any age with 25 years of service; the early retirement payments were reduced by seven percent per year under age 60 , and three percent per year from 60 to 65 . Retirees could choose from six annuity options as well as a partial lump-sum option.

The New Plan Options (Tier II). Employees hired after July 1, 2011, were required to choose between a DC plan and a hybrid plan; the election had to be declared prior to the end of their first

\footnotetext{
12 The 2013 Actuarial Valuation Report for the Utah Retirement Systems is available at https://www.urs.org/mango/pdf/urs/Miscellaneous/ActuarialValuationReport2013.pdf

13 The basic structure of this retirement plan is described in Tier 1 Noncontributory, https://www.urs.org/mango/pdf/urs/RetirementSystems/noncontrib.pdf
} 
year of employment; and the choice was final and irrevocable. Plan elections are made online, and employees failing to elect a plan prior by the end of their first year have been automatically enrolled into the default hybrid plan. During their first year of employment, employees are presented with a screen asking them to choose their retirement option each time they log into their retirement account. This screen includes links to educational materials about the plan choices. In order to proceed to view their account, employees must either select a plan or "I am not ready to my election at this time." The date when the plan choice becomes final, or when they are automatically enrolled in the hybrid, is prominently displayed on this page.

URS communication materials for new hires seek to present a balanced assessment of the two plan options, stating that "both plans have advantages and disadvantages. The plan that's better for you will depend on your situation." The webpage for new members outlines various aspects of each plan in detail and directs new employees to additional resources, including a “decision guide" and several online pension benefit estimate calculators.

An employee electing the DC plan receives an annual employer contribution of 10 percent of his annual earnings into the $401(\mathrm{k})$ account, ${ }^{14}$ and these employer contributions vest after four years of eligible employment. Employees may also make additional contributions to their accounts on a voluntary basis. Distributions are allowed after retirement, separation from of employment, or age $591 / 2$, and the funds may be withdrawn various ways, at the retiree's discretion. No cost of living adjustments are provided to DC participants. ${ }^{15}$

The hybrid plan is less generous than the old DB plan along several dimensions. First, the new retirement benefit is determined by multiplying the employee's years of service by 1.5

\footnotetext{
${ }^{14}$ Similar to other state plans, the URS Public Safety and Firefighters' plans are somewhat more generous, with a state contribution of 12 percent of salary, compared to general state employee plans.

${ }^{15}$ For an overview of cost of living increases in benefits in public pension plans, see NASRA (2014b).
} 
percent times the monthly average of his highest-five earnings years. Compared to the old DB plan, the new longer earnings averaging period is likely to lower the benefit. Second, the hybrid plan also requires participants to work for 35 years to qualify for a normal retirement benefit at any age, five years longer than under the old DB plan; participants may also take an unreduced retirement benefit at age 65 with four years of service. Retirees can take a reduced benefit beginning at age 62 with 10 years of service, or age 60 with 20 years of service; early retirement reduces benefits by about seven percent per year between age 60-63, and approximately nine percent per year for age 64-65. Third, the hybrid plan only permits up to a 2.5 percent cost of living benefit adjustment each year, depending on the change in the Consumer Price Index (CPI), versus a 4 percent rate under the old plan. Retirees may receive their maximum retirement benefits based on the formula, or they can select from several joint and survivorship options. Employees may also contribute to several voluntary retirement saving plans (to be described below).

The hybrid also has another key feature differentiating it from the old model: their contribution rates are variable. That is, the plan's Board of Trustees must set a certified contribution rate each year for the defined benefit portion of the hybrid plan, based on the preceding year's actuarial valuation. As long as the employer-certified rate remains below 10 percent of compensation, employees are not required to make any additional plan contributions. If the rate exceeds 10 percent, hybrid plan participants must contribute the entire amount needed. Conversely, if the employer's certified DB contribution rate were to fall below 10 percent, the employer then must contribute the difference between 10 percent of compensation and the certified rate into participants' 401(k) accounts. For example, in 2014-15, the employer's certified contribution rate was 8.22 percent of payroll; therefore, the employer contributed 1.78 
percent of payroll into employees' 401(k) accounts that year. ${ }^{16}$ Pension and employer contributions to the 401(k) account vest after four years of service.

Comparing the Tier I and Tier II Systems. Generally speaking, the new Tier II arrangement is anticipated to pay lower benefits, compared to the old Tier I DB plan. ${ }^{17}$ We illustrate the expected difference in retirement benefits assuming the relevant benefit formulas and various age/service thresholds for an unreduced benefit. Depending on the plan type (DB versus hybrid) and years of service, the outcomes may be compared as follows:

\begin{tabular}{|c|c|c|}
\hline \multirow[b]{2}{*}{$\begin{array}{l}\text { Years of } \\
\text { Service }\end{array}$} & \multicolumn{2}{|l|}{ Plan Type } \\
\hline & Tier I DB & Tier II Hybrid \\
\hline 10 & $\begin{array}{l}20 \% \times \text { average of highest } 3 \\
\text { years earnings }\end{array}$ & $\begin{array}{l}15 \% \times \text { average of highest } 5 \\
\text { years earnings }\end{array}$ \\
\hline 20 & $\begin{array}{l}40 \% \times \text { average of highest } 3 \\
\text { years earnings }\end{array}$ & $\begin{array}{l}30 \% \times \text { average of highest } 5 \\
\text { years earnings }\end{array}$ \\
\hline 30 & $\begin{array}{l}60 \% \times \text { average of highest } 3 \\
\text { years earnings }\end{array}$ & $\begin{array}{l}45 \% \times \text { average of highest } 5 \\
\text { years earnings }\end{array}$ \\
\hline
\end{tabular}

The hybrid plan also requires more years of service for normal retirement benefits at any age, 35 years compared to the 30 years for the Tier I benefit, and the early retirement reductions are larger in the hybrid plan. In addition, prior to 2011, state and education employees who were in the Tier I DB plan received a 1.5 percent employer contribution to the 401(k) plan. In other words, the generosity of the Tier II hybrid plan is substantially below that of the old Tier I scheme.

\footnotetext{
${ }^{16}$ The total employer contribution rate for both the DC plan and the hybrid plan includes an amount for amortization of the unfunded actuarial accrued liability in the Tier I System. This amount differs by employer group. For the fiscal year ending June 30, 2015, the Tier I unfunded liability rates that are paid by employers on behalf of members of the Tier II Public Employees System ranged from 6.61 percent to 9.94 percent.

${ }^{17}$ Retiree health provisions did not change for new hires during the time period of our analysis.
} 
While participants in the new Tier II DC and hybrid might conceivably generate higher retirement benefits if their DC returns proved to be much in excess of what the old DB would have paid, ${ }^{18}$ this seems unlikely. Moreover, the new structure clearly shifts risk from the employer to the employees. In the DC plan, participants bear all investment risk directly. The hybrid option also poses risk to participants for two reasons. First, if the cost of the DB portion of the plan exceeds 10 percent of payroll, workers will need to cover the excess. ${ }^{19}$ Second, employees also bear the potential cost of mismatched assets and liabilities in the hybrid plan, while not having any control over that plan's asset mix. While the educational materials given to employees plainly state that they will be responsible for contributing to the plan if the contribution rate ever exceeds 10 percent, there is no mention of the mechanisms affecting this extra contribution. Also, it is unclear whether this potential moral hazard on the part of the plan's investment managers is widely appreciated..$^{20}$

Supplemental Plans. Public employees also have the option of contributing to several supplemental retirement saving plans, though state agencies offer no employer match to employee contributions for general state employees. ${ }^{21}$ Currently URS offers a 401(k) plan, a 457

\footnotetext{
${ }^{18}$ Assuming that DC plan investments earn 6.5 percent compounded steadily for 30 years and the balance is annuitized for 25 years, NASRA (2014c) suggests that the payouts could be higher from Utah's hybrid plan than the traditional DB. This computation did not consider investment risk, longevity risk, or the 1.5 percent employer 401(k) contribution provided to state and education employees before the reform.

${ }^{19}$ There is also an interesting generational cross-subsidy element in the new plan, in that workers but not retirees will be required to cover excess costs over 10 percent of pay. In the event that longevity rose or investment earnings fell more than expected, active employees would be required to subsidize retirees. Whether participants understand this generational redistribution feature is unclear.

${ }^{20}$ For arguments against holding stock in DB plans, see for instance Bader and Gold (2007) and Black (1989).

${ }^{21}$ Participants in the Tier 1 Public Employees Noncontributory Retirement System still receive an additional employer contribution of 1.5 percent of their compensation in the 401(k) plan. All other employers also have the option of contributing to URS 401(k) and/or 457 Plans on behalf of their employees.
} 
plan, and a traditional as well as a Roth IRA. All URS members are eligible to participate in the IRA. With the introduction of Tier II, all employers are required to participate in the 401(k) plan and many also participate in the 457 plan. These supplemental plans provide eight core investment options along with target date funds. In addition, a self-directed brokerage account for pre-tax contributions is available through a private money manager. ${ }^{22}$ All employee contributions are immediately vested and thus may be cashed out when employment ends.

\section{Multivariate Determinants of Public Plan Choice}

New hires in the Tier II system must choose between enrolling in the hybrid plan or in the DC plan within one year after their initial employment. As noted above, employees who fail to make an active choice of primary plan option are automatically enrolled into the default hybrid plan. To examine who defaulted, and who chose which plan conditional on making an active choice, we analyze URS administrative records on all individuals who first entered employment with a URS-covered employer between January 1, 2006 and September 30, 2013. These records include information on employee age, sex, employment dates, and retirement plan choice, along with annual earnings, employee contributions to voluntary URS-administered retirement savings plans, service credit, and job classification for the period from January 1 , 2006 to October 31, 2014. Because plan choice decisions in the Tier II system do not become final and irrevocable until the end of the first year of employment, we restrict our attention to employees who did not separate from service in their first year on the job. After removing observations where age, gender, or earnings were missing, the resulting sample includes a "pre-

22 A description of these plans and their investment options can be found at https://www.urs.org/mango/pdf/urs/InvestmentOptions/2015/investmentOptions.pdf, https://www.urs.org/mango/pdf/urs/Savings/401kSummary.pdf, https://www.urs.org/mango/pdf/urs/Savings/457Summary.pdf 
reform" group of 38,220 employees hired before July 1, 2011, and a "post-reform" group of 16,095 individuals hired on or after July $1,2011 .^{23}$

Table 1 reports the plan choices of individuals hired post-reform along with the total number of new hires throughout the 2006-2014 period. Almost 60 percent of Utah's new hires after the reform took place failed to make an active choice between the two plan options and were therefore defaulted into the hybrid plan. This level of default is consistent with findings from other states that have offered workers a choice of primary retirement plans. ${ }^{24}$ One explanation for why so many people may have defaulted is behavioral inertia (Madrian and Shea 2001; Choi et al. 2004; Yang 2005). Another explanation might be that employees actually preferred the hybrid plan over the DC option. That is, some workers may have favored the hybrid plan and simply avoided the transaction cost of making an active choice producing the same outcome as doing nothing.

In Washington State where public sector workers were given a choice between a traditional DB versus a hybrid plan, Olleman (2009) found that close to 70 percent of employees rejected the hybrid plan default, instead actively selecting the traditional DB plan. Brown, Farrell, and Weisbenner (2015) examined pension plan defaults by members of the Illinois State Universities Retirement System, where they found that only 27 percent of their survey respondents reported being defaulted. Nevertheless, their defaulters were more likely to wish they had chosen an alternative plan compared to those that made an active decision. As the

\footnotetext{
${ }^{23}$ Appendix Table 2 provides details on the data construction and how specific variables are defined. Members of the Governors' and Legislators' Retirement Plan, and the Judges' Retirement System, are excluded from our analysis.

${ }^{24}$ In states that offer their workers choice of DB or DC plans, Olleman (2009) reports that 39 percent of Colorado new hires are defaulted into the DB plan, 55 percent in Florida, 82 percent of Ohio PERS and 72 percent of Ohio teachers.
} 
traditional DB plan was no longer offered in Utah, it seems likely that some URS participants defaulted to the hybrid plan because they favored it, while others' choice was likely to have been due to inertia.

\section{Table 1 here}

Of the approximately 40 percent of URS new hires who actively elected a retirement plan, slightly over half selected the hybrid plan, and slightly fewer (48 percent) chose the DC. We also see that the proportion of individuals actively selecting the hybrid plan increased over time, and the ratio of people defaulting shrank somewhat. This contrasts with the case of Illinois, where Brown and Weisbenner (2014) found that the proportion of individuals selecting the default grew over time.

To elucidate some of the demographic and other factors associated with workers' tendency to make an active choice of retirement plan options rather default into a plan, Table 2 presents descriptive statistics for new hires between January 1, 2006 and September 30, 2013. The table first reports characteristics of all sample individuals, and then it highlights a number of subgroups including pre-reform workers, post-reform workers, workers who made an active choice, workers who made a passive choice, and all workers who chose each plan option. For each of these subgroups, we report classifications by employer type and pension system. The largest group is public school employees who comprise 47 percent of the URS population. Higher education staffers comprise 11 percent of the sample; university faculty are excluded from this system. Local governmental employees account for almost a quarter of the sample, and state employees constitute 18 percent of the sample. The majority of the sample is covered by the Public Employees' Retirement System, and an additional 7 percent are members of the more generous Public Safety and Firefighters' System. Most new hires are women (62 percent), and 
the average salary earned in the second calendar year of employment (the "plan choice year") was around $\$ 32,000$ in 2014 dollars. The average entry age across all workers in our sample is 33.3, although individuals hired after the reform were slightly younger than those hired before the reform.

Table 2 here

Separation rates during the second year of employment were 4 percentage points higher for the post-reform group, at about 17 percent, versus around 13 percent for the pre-reform group. ${ }^{25}$ Almost 35 percent of pre-reform new hires made voluntary contributions to one of the supplemental retirement plans offered by URS during the plan choice year, but only 18 percent of the post-reform sample contributed to these plans. The average amount contributed by supplemental plan participants was 4.4 percent of salary and did not differ between the prereform and post-reform groups.

Table 3 categorizes workers by individual and job characteristics, and it also shows the percentage of new hires in each subgroup electing each plan option. A higher proportion of men made an active choice. Women were more likely to opt for the DC plan, among those making an active plan choice. Employees with higher initial salaries were also more likely to make an active choice. Employees working at educational institutions were more likely to default into the hybrid, while general government employees were more likely to make an active choice. Educational employees who made an active choice were more likely to choose the DC plan, while general government employees who made an active choice were more likely to choose the hybrid plan. In summary, defaulters differed from the active choosers in a number of ways. On

\footnotetext{
${ }^{25}$ This reflects separations reported before November 1, 2014 for individuals hired before September 30, 2012.
} 
average, defaulters were two years younger, made $\$ 6,000$ less per year, were much less likely to be employed in state government, and were more likely to be in public education.

\section{Table 3 here}

We explore these patterns further using multivariate regression analysis, with results provided in Table 4. Six linear probability models are presented, ${ }^{26}$ with two specifications for each of three dependent variables: (i) enrolled in hybrid plan whether by default or active choice, (ii) made an active choice, and (iii) chose the DC given that an active choice was made. The first specification for each dependent variable includes a vector of individual and job characteristics, while the second specification also controls on two actions taken after the plan choice: whether the new hire separated from employment, and whether the new hire contributed to a supplemental retirement savings plan.

\section{Table 4 here}

The first column presents results for models of whether new hires enrolled in the hybrid plan, either by default or by active choice. Here we see that state government employees (the reference category in this equation) were 5-7 percentage points less likely to participate in the hybrid plan than were local government, public education, or higher education employees. Members of the Public Safety \& Firefighters' system were also more likely to enroll in the hybrid, as were men and the lower-paid.

Column 3 of Table 4 reports on which newly hired employees made an active election of their retirement plan; the model posits that defaulters differ from participants who made an active choice. Results indicate that new hires age $45+$ over were more likely, and those younger than 25

\footnotetext{
${ }^{26}$ Appendix Table 3 presents similar results from a series of Probit models. The marginal effects in the two procedures are similar in sign and magnitude.
} 
less likely, to make an active choice compared to those age 25-29. Men tended not to make an active selection, while state government employees were significantly more likely to make an active choice compared to those in higher education, local government, or public education. Interestingly, in each succeeding year, new hires were increasingly likely to make an active election, perhaps reflecting growing knowledge about the two plans and their differences.

Column 5 of Table 4 shows which persons making an active selection chose the DC plan. Among these employees, older persons were more likely to select the hybrid plan, perhaps because they expected to be less likely to change jobs in the future. Conditional on making an active choice, men chose the hybrid plan more often, while the higher paid elected the DC plan. Higher education staffers were nine percentage points less likely to elect the hybrid plan, perhaps indicating their greater anticipated career mobility. Over time, a larger percentage of new hires who made an active choice selected the hybrid plan.

Two additional variables are included in Columns 2, 4, and 6 of Table 4, in an effort to control for factors indicative of additional difficult-to-observe information about new hires. Specifically, we examined whether each participant subsequently contributed to a URS supplemental retirement plan, and whether each separated from employment in the second year on the job. Interestingly, participants who did save in the supplemental plans were also more likely to have made an active pension choice in their first year. In other words, these individuals appear to have been more attentive than average to retirement plan features. By contrast, workers leaving employment in their second year were less likely to have made an active plan choice, and when they did, they chose the DC plan more often. Thus, the defaulters are also more likely to anticipate that they will leave public employment. 


\section{Did the Reform Boost Supplemental Retirement Saving?}

If new hires understand that the post-reform retirement plans are likely to be less generous than the old DB plan, they may make an effort to save more in the supplemental retirement plans to accumulate sufficient retirement resources. ${ }^{27}$ To test for this, we have calculated participation and contribution patterns in supplemental retirement plan for pre- and post-reform new hires. These are based on employee contributions to URS supplemental plans and do not include employer contributions to the 401(k) plan associated with the hybrid or DC plan.

Figure 2 and Table 5 reveal the time path of supplemental plan participation over the period. Of note is the long-term decline in supplemental plan participation throughout the period, most likely attributable to the recession and collapse of the equity markets. Prior to the reform, the proportion of new hires enrolling in supplemental plans fell from over 40 percent (2006-08) to only about 25 percent for those hired 2009-11. Post-reform, the proportion of new hires contributing to a supplemental plan continued to fall, to below 20 percent. The average contribution rate remained relatively stable over the period, at around 4.4 percent.

Figure 2 also shows that employees who defaulted into the hybrid plan post-reform were far less likely to contribute to supplemental accounts, compared to new hires making an active plan choice. Table 5 also shows that defaulters who did make voluntary contributions, saved less on average than did active choosers. Participation rates for those making an active election were actually higher than pre-reform (33 percent compared to about 25 percent) while those who defaulted into the hybrid plan were much less likely to save additional amounts (7 percent). Finally, those who elected the hybrid plan were somewhat more likely to enroll in one of the

\footnotetext{
${ }^{27}$ Indeed the NASRA (2014c) report states that "public employees will need to take advantage of supplemental savings vehicles to maintain similar salary replacement rates in retirement, pre and post reform" (p.14).
} 
supplemental saving plans, compared to those choosing the DC, but they contributed less as a percentage of pay, on average, than participants who chose the DC.

\section{Figure 2 and Table 5 here}

A multivariate linear probability analysis of the time pattern shows that some, but far from all, new hires with the less generous Tier II pensions responded by voluntarily contributing to a retirement saving plan; see Table $6{ }^{28}$ As one might expect, more highly paid new hires were more likely to contribute to the supplemental plan, as were older employees. ${ }^{29}$ Nevertheless, age is not significant for state employees. The key finding, however, is that participants making an active election of primary plan were about 22 percentage points more likely to also participate in a supplemental plan, holding other factors constant (Column 1). Some individuals in our sample might be participating in other supplemental plans offered by their employers, ${ }^{30}$ and we have data only on contributions to URS Savings Plans. Accordingly, Column 2 breaks out state employees for whom we observe all participation in employer-provided supplemental retirement plans. Results show even greater differences: those actively choosing their primary plan were 41 percentage points more likely to make supplementary contributions, versus those defaulted into the hybrid plan.

\section{Table 6 here}

Columns 3 and 4 of Table 6 expand on this analysis by focusing on contribution rates for supplemental plan participants. Contribution rates were positively associated with age and salary,

\footnotetext{
${ }^{28}$ Appendix Table 4 presents similar results from a series of Probit models. The marginal effects in the two procedures are similar in sign and magnitude.

${ }^{29}$ Beshears, Choi, Laibson, and Madrian (2009) have shown that low-paid employees were more susceptible to the influence of defaults due to barriers to active decision-making.

${ }^{30}$ Public universities, community colleges, and many school districts offer their own 457 and 403(b) plans and some local governments offer 457 plans.
} 
and men contribute less than women. For state employees, however, salary was not significant. Participants in the DC primary plan contributed more than participants in the hybrid plan.

\section{How the Reform Affected Patterns of Separation from Public Employment}

One concern sometimes expressed by public sector employers who alter their retirement plans is that such changes will influence employee separation rates. ${ }^{31} \mathrm{We}$ can evaluate this hypothesis in the URS case, since the dataset includes separations reported prior to November 1, 2014 for individuals who remained employed for at least one year. Our pre-reform series begins with new hires during the final six months of fiscal year 2006, extends through the recession years, and ends with fiscal year 2011. The post-reform data includes employees hired during fiscal year 2012 and the first three months of fiscal year 2013. Inasmuch as there is a 30-60 day lag in reporting, we restrict the sample for this analysis to individuals hired prior to September 30, 2012. ${ }^{32}$ We cannot determine whether separations were employee-initiated quits or employer-initiated terminations.

Figure 3 reports the proportion of pre- and post-reform new hires who remained employed for at least two years; that is, the second-year retention rate conditional on remaining on the job at least one year. Table 7 shows that more than 87 percent of those hired prior to the reform were still employed two years later, while fewer than 83 percent of those hired after the reform remained at the two-year mark. In other words there was a considerable increase in separation rates after the reform was enacted, of 30 percent (from 13 to 17 percentage points). It is also interesting that new hires not making an active choice of a pension plan post-reform had

\footnotetext{
${ }^{31}$ In fact, this research project began with a conversation with Richard Ellis, Treasurer of the State of Utah in which he indicated his concern that turnover rates had risen since the implementation of the pension reforms.

${ }^{32}$ Additionally, we removed 43 individuals who separated from employment due to death or disability.
} 
considerably higher separation rates, compared to the new hires who elected either the DC or the hybrid plan. That is, people who elected the DC plan had slightly higher separation rates compared to those in the hybrid plan.

\section{Figure 3 and Table 7 here}

In Table 8, we report estimated coefficients of a model of the factors determining whether an employee remained on the job after one year of employment. Three groups are of interest: post-reform hires, the full sample, and individuals hired within one year before and after the reform. ${ }^{33}$ Once again, we see that people who defaulted into the hybrid plan behave differently, compared to those making an active choice. Employees who actively elected the hybrid plan were eight percentage points more likely to remain on the job compared to the defaulters, and new hires electing the DC plan were two percentage points more likely to remain on the job versus the defaulters. Moreover, the separation rate post-reform was about four percentage points higher than in pre-reform years. Older employees were less likely to leave public employment, as were men and those with higher annual salaries.

\section{Table 8 here}

While these results are suggestive, it is still difficult to prove that the Utah pension reform drove the increase in the two-year separation from public employment. As noted earlier, the pension reform reduced expected retirement benefits for public employees, which would be consistent with this conclusion. Moreover, if public employment became less desirable, new hires many have been lower-quality workers; in response, job evaluations could have fallen and employer-initiated terminations may have risen. Yet separations could also have risen due to the

\footnotetext{
${ }^{33}$ Appendix Table 5 presents similar results from a series of Probit models. The marginal effects in the two procedures are similar in sign and magnitude.
} 
recovering economy. From January 2009 to July 2011, the unemployment rate in Utah ranged between 6.3 and 8.0 percent. As the national economy recovered, Utah's unemployment rate dropped rapidly, to 3.7 percent in 2014 , the final year of our sample. A corresponding rise in employment was also observed in the state: comparing the pre-reform with the post-reform period employment rose about 10 percent. ${ }^{34}$ Accordingly, the state's rapidly-improving economy could have induced more public employees to leave their state and local jobs.

While we cannot precisely estimate the relative importance of these effects, it seems likely that the pension reform was not the only factor in increased public sector employee separation rates. It is clear; however, that separations increased while the retention rate declined around the time of the pension reform. To more narrowly focus the analysis around the time of the reform, Figure 4 plots retention rates by quarters before and after the reform became effective. There is a clear change in the level of retention and a steeper drop after the implementation of the reform.

\section{Conclusion and Discussion}

State and local governmental pension managers across the United States confront important financial challenges due to low pension funding ratios and rapidly rising contributions required to maintain these plans. In response to this financial challenge, many public sector employers have modified their retirement plans to reduce both their current annual pension costs and future pension liabilities. A few states have implemented more systematic changes, freezing their traditional DB plans and instead offering employees a choice of alternatives that shift investment risk away from employers and onto employees. Utah is a prime example of a state

\footnotetext{
${ }^{34}$ These employment and unemployment data are from the BLS databases on state labor markets (accessed April 17, 2015). http://data.bls.gov/timeseries/LASST490000000000003
} 
that has fundamentally altered its retirement plan for newly hired workers, by replacing its traditional DB plan with the choice of a hybrid plan or a DC. Our analysis contributes to the relatively limited literature by examining the impact of public retirement plan reform on Utah's public sector workforce.

Similar to other studies, we find that a majority (about 60 percent) of the URS new hires defaulted into the hybrid plan. Among those who did make an active choice, slightly more than half selected the hybrid plan, and the remainder chose the DC plan. Our analysis goes further in evaluating the impact of public pension reform by examining employee behavior post-reform. Since the new plan options are anticipated to yield less generous benefits than the old DB plan, we evaluate whether new hires saved more, compared to pre-reform employees, and whether the new plan led to higher turnover rates. Our analysis of participation in supplemental saving plans spans the Great Recession, so it is difficult to draw unambiguous conclusions. Nevertheless, we find that, post-reform, fewer new hires enrolled in supplemental retirement plans compared to pre-reform, so they did not respond to lower expected retirement incomes by increasing their retirement saving. Interestingly, however, new hires who did make an active plan choice were also more likely to enroll in the supplemental plan than pre-reform new hires: 33 percent of individuals making an active choice enrolled in a supplemental plan during the post-reform period, compared to around 25 percent in the three years before the reform was enacted. By contrast, those defaulting into the hybrid plan had lower enrollment rates in supplemental plans. In other words, this analysis suggests that people who are defaulters in one dimension - failing to make a choice of their primary plan - also fail to make an active choice in other areas, like enrolling in a supplemental plan. 
We also evaluated whether the less generous retirement system is associated with higher separation rates among new hires, and here we found that 4 percent more new hires left public employment in Utah post-reform, compared to beforehand. We must caveat this conclusion by noting that post-reform turnover could also reflect a recovering labor market compared to the years prior to the plan change. In other words, if job opportunities improved post reform, newlyhired public employees may have had other employment options to consider.

It is also likely that many workers' failure to make active retirement plan choices could spur plan administrators to provide financial education programs and opportunities to learn about the retirement benefits offered. This could enhance their old age provisions, and might also reduce turnover among new hires. As yet we cannot determine precisely how these reforms will influence public employees' retirement patterns, nor do we estimate cost savings to the state or taxpayers associated with the reform in this paper. But we do believe that defaults in pension reforms shape public workers' employment, saving, and turnover behaviors. Consequently, public sector pension managers and policymakers may wish to consider these effects when evaluating future pension reforms. 


\section{References}

Allen, Steven, Robert Clark, and Ann McDermed. (1993). "Pensions, Bonding, and Lifetime Jobs." Journal of Human Resources 28(3): 463-81.

Bader, Lawrence N. and Jeremy Gold. (2007). "The Case against Stock in Public Pension Funds." Financial Analysts Journal. 63(1): 55-62.

Beshears, John, James J. Choi, David Laibson, and Brigitte C. Madrian. (2009). "The Importance of Default Options for Retirement Saving Outcomes: Evidence from the United States." In Social Security Policy in a Changing Environment. Editors: Jeffrey Brown, Jeffrey Liebman and David Wise. Chicago: University of Chicago Press: 167-195.

Black, Fischer. (1989). “Should You Use Stocks to Hedge Your Pension Liability?” Financial Analysts Journal. 45(1): 10-12.

Brown, Jeffrey, Anne Farrell, and Scott Weisbenner. (2015) "Decision-Making approaches and the Propenstity to Default: Evidence and Implications.” NBER Working Paper 20949.

Brown, Jeffrey and Scott Weisbenner. (2014). "Why do Individuals Choose Defined Contribution Plans? Evidence from Participants in a Large Public Plan.” Journal of Public Economics, 16: 35-46.

Chalmers, John, Woodrow T. Johnson, and Jonathan Reuter. (2008). "The Effect of Pension Design on Employer Costs and Employee Retirement Choices: Evidence from Oregon.” Review of Economics \& Statistics. 90(2): 253-266.

Chingos, M. M. and M.R. West. (2013). When Teachers Choose Pension Plans: The Florida Story. The Thomas Fordham Institute. http://edex.s3-us-west2.amazonaws.com/publication/pdfs/20130219-When-Teachers-Choose-Pension-PlansFINAL_6_0.pdf 
Choi, James J., David Laibson, Brigitte C. Madrian, and Andrew Metrick. (2004) "For Better or for Worse: Default Effects and 401 (k) Savings Behavior." In Perspectives on the Economics of Aging. Editor: David Wise.Chicago: University of Chicago Press: 81-126.

Clark, Robert, Lee Craig, and Neveen Ahmed. (2009). “The Evolution of Public Sector Pension Plans in the United States.” In Gary Anderson and Olivia Mitchell (eds.), The Future of Public Retirement Systems. Oxford: Oxford University Press: 239-270.

Clark, Robert L., Lee A. Craig, and Jack W. Wilson. (2003). A History of Public Sector Pensions in the United States. Philadelphia: University of Pennsylvania Press.

Clark, Robert and Emma Hanson. (2011). "Distribution Options in State Pension Plans.” North Carolina State University Working Paper.

Clark, Robert, Linda Ghent, and Ann McDermed. (2006). "Pension Plan Choice among University Faculty.” Southern Economic Journal. 72(3): 560-577.

Clark, Robert and Fred Munzenmaier. (2001) "Impact of Replacing a Defined Benefit Pension with a Defined Contribution Plan or a Cash Balance Plan.” North American Actuarial Journal. 5(1): 32-56.

Clark, Robert and Melinda Pitts. (1999). "Faculty Choice of a Pension Plan: Defined Benefit vs. Defined Contribution," Industrial Relations, 38(1): 18-45.

Dallof, Sarah. (2010). “Thousands Rally at Capitol to Protest Retirement Bills.” KSL-TV Salt Lake City, February 6. http://www.ksl.com/?sid=9602428

Evans, Richard and Kerk Phillips. (2014). "Simulating State Pension Reform: The Utah Retirement System.” BYU Macroeconomics and Computational Laboratory Working Paper \#2012-01, accessed March 15, 2015. https://economics.byu.edu/Documents/Macro\%20Lab/Working\%20Paper\%20Series/BYU 


\section{MCL2012-01.pdf}

Glaeser, Edward L. and Giacomo Ponzetto. (2014). "Shrouded Costs of Government: The Political Economy of State and Local Public Pensions.” Journal of Public Economics 116: 89-105.

Goldhaber, Dan, and Cyrus Grout. (2013). "Which Plan to Choose? The Determinants of Pension System Choice for Public School Teachers." Journal of Pension Economics and Finance 12(1): 1-25.

Greenhouse, Steven. (2011). "States Lean on Public Workers for Bigger Pension Contributions." New York Times, June 15. http://www.nytimes.com/2011/06/16/business/16pension.html

Gustman, Alan and Olivia S. Mitchell. (1992). "Pensions and the US Labor Market." In Pensions and the Economy, eds Z. Bodie \& A. Munnell. Philadelphia, PA: Univ. of Pennsylvania Press: 39-87.

Gustman, Alan S., Olivia S. Mitchell, and Thomas Steinmeier. (1994). "The Role of Pensions in the Labor Market.” Industrial and Labor Relations Review 47(3): 417-438.

Gustman. Alan S. and Thomas L. Steinmeier. (1995). Pension Incentives and Job Mobility. Kalamazoo: Upjohn Institute Press.

Lachance, Marie-Eve, Olivia S. Mitchell, and Kent Smetters. (2003). "Guaranteeing Defined Contribution Pensions: The Option to Buy Back a Defined Benefit Promise.” Journal of Risk and Insurance. 70(1): 1-16.

Lusardi, Annamaria and Olivia S. Mitchell. (2014). “The Economic Importance of Financial Literacy: Theory and Evidence." Journal of Economic Literature. 52(1): 5-44.

Lyman, Richard and Mary Williams Walsh, (2014). "Public Pension Tabs Multiply as States Defer Costs and Hard Choices." New York Times Feb. 24. 
Madrian, Brigitte C., and Dennis F. Shea. (2001) "The Power of Suggestion: Inertia in 401 (k) Participation and Savings Behavior." The Quarterly Journal of Economics. 116(4), 11491187.

McGuinn, Patrick. (nd). "Pension Politics: Public Employee Retirement System Reform in Four States." The Brookings Institution. http://www.scribd.com/doc/209405194/Pension$\underline{\text { Politics-Public-Employee-Retirement-System-Reform-in-Four-States\#scribd_Accessed }}$ March 11, 2015).

Milevsky, Moshe, A. Promislow and S. David. (2004). “Florida's Pension Election: From DB to DC and Back," The Journal of Risk and Insurance 71(3): 381-404.

Mitchell, Olivia S. (2012). "Public Pension Pressures.” In When States Go Broke: The Origins, Context, and Solutions for the American States in Fiscal Crisis. Ed. Peter Conti-Brown. Cambridge, UK: Cambridge University Press: 57-76.

Mitchell, Olivia S., Steve Utkus, and Tongxuan (Stella) Yang. (2007). “Turning Workers into Savers? Incentives, Liquidity, and Choice in 401(k) Plan Design.” National Tax Journal. 60: 469-89.

Munell, Alicia H., Jean-Pierre Aubry, and Mark Cafarelli. (2014). "Defined Contribution Plans in the Public Sector: An Update.” 37. Working Paper, Center for Retirement Research at Boston College.

National Association of State Retirement Administrators (NASRA 2010). "Retirement Plan Options for State University Faculty and Staff.” http://www.nasra.org/files/Compiled\%20Resources/HigherEdPlanOptions.pdf

National Association of State Retirement Administrators (NASRA, 2014a). "Effects of Pension Plan Changes on Retirement Security.” 
http://www.nasra.org/files/JointPublications/Effects\%20of\%20Pension\%20Plans\%20on \%20Retirement $\% 20$ Income.pdf

National Association of State Retirement Administrators (NASRA, 2014b). "Cost-of-Living Adjustments." Issue Brief. http://www.nasra.org/files/Issue\%20Briefs/NASRACOLA\%20Brief.pdf

National Association of State Retirement Administrators (NASRA, 2014c). "Shared Risk in Public Retirement Plans.” Issue Brief. http://www.nasra.org/files/Issue\%20Briefs/NASRASharedRiskBrief.pdf

Novy-Marx, Robert and Joshua D. Rauh. (2015). "Linking Benefits to Investment Performance in US Public Pension Systems.” Journal of Public Economics. 116: 47-62.

Olleman, Mark. (2009). "Public Plan DB/DC Choices.” PERiScope, Chicago: Milliman.

Pew Center on the States. (2010a). Roads to Reform: Changes to Public Sector Retirement Benefits Across States. Washington, D.C.: Pew Center.

Pew Center on the States. (2010b). The Trillion Dollar Gap. Washington, D.C.: Pew Center.

Walsh, Mary Williams. (2011). "Two Rulings Find Cuts in Public Pensions Permissible.” New York Times, June 30.

Yang, Tongxuan. (2005) "Understanding the Defined Benefit versus Defined Contribution Choice." Pension Research Council Working Paper, Wharton School, \#2005-4. 
Table 1. Plan Choice by Newly-Hired Utah Public Employees

\begin{tabular}{|c|c|c|c|c|c|c|}
\hline \multirow{2}{*}{\multicolumn{2}{|c|}{ Entry Date }} & \multicolumn{4}{|c|}{ Plan Choice } & \multirow[b]{2}{*}{ Observations } \\
\hline & & Chose DC & Chose Hybrid & $\begin{array}{c}\text { Defaulted into } \\
\text { Hybrid }\end{array}$ & $\begin{array}{c}\text { Defaulted into } \\
D B\end{array}$ & \\
\hline \multicolumn{7}{|c|}{ Fiscal Year Ending } \\
\hline June 30, & $2006^{\circ}$ & & . & & 100.0 & 2,709 \\
\hline & 2007 & & . & & 100.0 & 8,546 \\
\hline & 2008 & & . & & 100.0 & 8,927 \\
\hline & 2009 & & 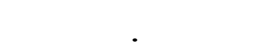 & & 100.0 & 6,898 \\
\hline & 2010 & & . & & 100.0 & 5,326 \\
\hline & 2011 & & & & 100.0 & 5,814 \\
\hline & 2012 & 20.4 & 19.0 & 60.6 & . & 6,333 \\
\hline & 2013 & 19.4 & 23.5 & 57.1 & . & 6,698 \\
\hline & 2014 & 21.1 & 24.9 & 54.0 & & 3,064 \\
\hline \multicolumn{2}{|c|}{ Pre-Reform } & & & & 100.0 & 38,220 \\
\hline \multicolumn{2}{|c|}{ Post-Reform } & 20.1 & 22.0 & 57.9 & & 16,095 \\
\hline & All & 6.0 & 6.5 & 17.2 & 70.4 & 54,315 \\
\hline
\end{tabular}

Note: The table indicates the percentage of new hires who choose or were defaulted into each plan. Employees who first entered employment with a Utah Retirement Systems-covered employer between January 1, 2006 and September 30, 2013 and did not separate from employment during the first 12 months are included. The pre-reform group includes individuals hired before July 1, 2011 who were automatically enrolled in a traditional defined benefit (DB) plan. The post-reform group includes individuals hired on or after July 1, 2011 who were given the choice between a defined contribution (DC) plan and a hybrid plan. Plan choice elections become final at the end of the first year of employment. Individuals in the post-reform group who did not make an active election during the first year were defaulted into the hybrid plan. The fiscal year ending June 30, 2006 includes only individuals hired during the six-month period beginning January 1, 2006. The fiscal year ending June 30, 2014 includes only individuals hired during the three-month period ending September 30, 2013. 
Table 2. Descriptive Statistics for Analysis Sample (in \% unless otherwise noted)

\begin{tabular}{|c|c|c|c|c|c|c|c|c|}
\hline Variable & $\begin{array}{c}\text { Full } \\
\text { Sample } \\
(1)\end{array}$ & $\begin{array}{l}\text { All Pre- } \\
\text { Reform } \\
\text { (2) }\end{array}$ & $\begin{array}{l}\text { All Post- } \\
\text { Reform } \\
\text { (3) }\end{array}$ & $\begin{array}{c}\text { Made Active } \\
\text { Choice } \\
(4)\end{array}$ & $\begin{array}{c}\text { Chose } \\
\text { DC } \\
(5)\end{array}$ & $\begin{array}{l}\text { Chose } \\
\text { Hybrid } \\
(6)\end{array}$ & $\begin{array}{l}\text { Defaulted } \\
\text { into Hybrid } \\
\text { (7) }\end{array}$ & $\begin{array}{c}\text { All Hybrid } \\
\text { (8) }\end{array}$ \\
\hline \multicolumn{9}{|l|}{ Employer } \\
\hline Higher Education & 11.0 & 11.0 & 10.9 & 9.2 & 10.9 & 7.5 & 12.1 & 10.9 \\
\hline Local Government & 24.5 & 26.0 & 20.8 & 23.4 & 20.0 & 26.5 & 19.0 & 21.0 \\
\hline Public Education & 47.0 & 45.1 & 51.5 & 44.2 & 46.1 & 42.5 & 56.7 & 52.8 \\
\hline State Government & 17.5 & 17.8 & 16.8 & 23.3 & 23.0 & 23.5 & 12.2 & 15.3 \\
\hline \multicolumn{9}{|l|}{$\underline{\text { System }}$} \\
\hline Public Employees & 93.5 & 92.9 & 94.8 & 93.6 & 95.7 & 91.7 & 95.7 & 94.5 \\
\hline Public Safety \& Firefighters & 6.5 & 7.1 & 5.2 & 6.4 & 4.3 & 8.3 & 4.3 & 5.4 \\
\hline \multicolumn{9}{|l|}{ Demographics } \\
\hline Entry age (in years) & 33.3 & 33.4 & 33.1 & 34.3 & 33.3 & 35.2 & 32.3 & 33.1 \\
\hline Salary in plan choice year ${ }^{*}$ & $\$ 32,334$ & $\$ 32,595$ & $\$ 31,712$ & $\$ 35,735$ & $\$ 36,708$ & $\$ 34,843$ & $\$ 28,789$ & $\$ 30,456$ \\
\hline Male & 38.3 & 38.6 & 37.4 & 40.2 & 36.4 & 43.8 & 35.4 & 37.7 \\
\hline \multicolumn{9}{|l|}{ Actions after choice } \\
\hline$\overline{\text { Separated in second year }} \wedge$ & 13.8 & 12.9 & 17.2 & 12.5 & 15.9 & 9.0 & 20.3 & 17.6 \\
\hline Contributed to SRP in plan choice year ${ }^{\#}$ & 29.7 & 34.5 & 18.2 & 33.9 & 32.3 & 35.5 & 6.8 & 14.7 \\
\hline Amount contributed in plan choice year ${ }^{*+}$ & $\$ 1,617$ & $\$ 1,601$ & $\$ 1,691$ & $\$ 1,787$ & $\$ 2,001$ & $\$ 1,609$ & $\$ 1,347$ & $\$ 1,521$ \\
\hline Contributions as percent of salary $^{+}$ & 4.4 & 4.4 & 4.4 & 4.6 & 5.0 & 4.2 & 3.8 & 4.1 \\
\hline Observations & 54,315 & 38,220 & 16,095 & 6,773 & 3,233 & 3,540 & 9,321 & 12,861 \\
\hline
\end{tabular}

Note: This table includes employees who first entered employment with a URS covered employer between January 1, 2006 and September 30, 2013 and did not separate from employment during the first 12 months. Individuals with missing information are excluded. *Salary and contribution amounts are reported in 2014 dollars. ${ }^{\#}$ SRP=Supplemental Retirement Plan (e.g. 401(k), 457)

${ }^{+}$Among those who contributed in the plan choice year and did not exceed IRS contribution limits.

Reflects separations reported before November 1, 2014 for individuals hired before September 30, 2012. Separations due to death or disability are excluded. The number of observations for this row is given in the last row of Appendix Table 2. 
Table 3. Plan Choice by Group

\begin{tabular}{|c|c|c|c|}
\hline Variable & $\begin{array}{c}\text { Chose DC } \\
\text { (1) }\end{array}$ & $\begin{array}{c}\text { Chose Hybrid } \\
\text { (2) }\end{array}$ & $\begin{array}{l}\text { Defaulted to Hybrid } \\
\text { (3) }\end{array}$ \\
\hline \multicolumn{4}{|l|}{ Employer } \\
\hline Higher Education & 20.2 & 15.3 & 64.6 \\
\hline Local Government & 19.3 & 28.0 & 52.7 \\
\hline Public Education & 18.0 & 18.2 & 63.9 \\
\hline State Government & 27.4 & 30.7 & 41.9 \\
\hline \multicolumn{4}{|l|}{ System } \\
\hline Public Employees & 20.3 & 21.3 & 58.4 \\
\hline Public Safety \& Firefighters & 16.5 & 35.3 & 48.2 \\
\hline \multicolumn{4}{|l|}{$\underline{\text { Entry age }}$} \\
\hline Under 25 & 18.4 & 15.2 & 66.4 \\
\hline $25-29$ & 21.9 & 21.6 & 56.5 \\
\hline $30-34$ & 21.1 & 24.7 & 54.2 \\
\hline $35-39$ & 20.6 & 22.8 & 56.6 \\
\hline $40-44$ & 18.2 & 24.7 & 57.1 \\
\hline 45 and Above & 20.0 & 28.6 & 51.4 \\
\hline \multicolumn{4}{|l|}{$\underline{\operatorname{Sex}}$} \\
\hline Female & 20.4 & 19.8 & 59.8 \\
\hline Male & 19.5 & 25.7 & 54.7 \\
\hline \multicolumn{4}{|l|}{ Salary in plan choice year } \\
\hline Under $\$ 10,000$ & 9.0 & 8.0 & 82.9 \\
\hline$\$ 10,000-\$ 19,999$ & 13.1 & 12.3 & 74.6 \\
\hline$\$ 20,000-\$ 29,999$ & 21.4 & 15.3 & 63.3 \\
\hline$\$ 30,000-\$ 39,999$ & 24.3 & 22.8 & 52.9 \\
\hline$\$ 40,000-\$ 49,999$ & 27.1 & 26.0 & 47.0 \\
\hline$\$ 50,000$ and Above & 29.3 & 35.6 & 35.1 \\
\hline \multicolumn{4}{|c|}{ Employment status year after plan choice year } \\
\hline Separated & 18.5 & 10.2 & 71.3 \\
\hline Active & 20.4 & 21.3 & 58.4 \\
\hline \multicolumn{4}{|c|}{ Suppl. Plan participation in plan choice year } \\
\hline Not Contributing & 16.7 & 17.4 & 66.0 \\
\hline Contributing & 35.5 & 42.8 & 21.7 \\
\hline Observations & 3,233 & 3,540 & 9,321 \\
\hline
\end{tabular}

Note: The table provides the percentage of new hires with a given characteristic who made plan choices given in the column headings. It includes employees who first entered employment with a URS-covered employer between January 1, 2006 and September 30, 2013 and did not separate from employment during the first 12 months. Individuals with missing information are excluded.

Reflects separations reported before November 1, 2014 for individuals hired before September 30, 2012. The number of observations for this row is given in the last row of Appendix Table 2. 
Table 4. Multivariate Estimates of Determinants of Plan Choice (OLS, robust standard errors in parentheses)

\begin{tabular}{|c|c|c|c|c|c|c|}
\hline \multirow[b]{2}{*}{ Independent Variable } & \multicolumn{6}{|c|}{ Dependent Variable } \\
\hline & \multicolumn{2}{|c|}{$\begin{array}{c}\text { Hybrid } \\
\text { (by default or choice) } \\
\text { (1) }\end{array}$} & \multicolumn{2}{|c|}{ Any Active Choice } & \multicolumn{2}{|c|}{$\begin{array}{c}\text { Choose DC } \\
\text { (given active choice) }\end{array}$} \\
\hline Entry & & & $\begin{array}{c}-0.056^{* * *} \\
(0.011)\end{array}$ & $\begin{array}{r}-0.05 \\
(0.0\end{array}$ & $\begin{array}{l}0.032 * \\
(0.018)\end{array}$ & $\begin{array}{c}0.029 \\
(0.018)\end{array}$ \\
\hline Entry Age: 3 & & $\begin{array}{c}0.016 \\
(0.011)\end{array}$ & $\begin{array}{c}0.010 \\
(0.013)\end{array}$ & $\begin{array}{c}0.005 \\
(0.012)\end{array}$ & $\begin{array}{c}-0.043^{* *} \\
(0.020)\end{array}$ & $\begin{array}{c}-0.043^{* *} \\
(0.019)\end{array}$ \\
\hline Entry A & & & $\begin{array}{c}0.004 \\
(0.014)\end{array}$ & $\begin{array}{c}0.001 \\
(0.013)\end{array}$ & $\begin{array}{c}-0.043^{* *} \\
(0.022)\end{array}$ & $\begin{array}{l}-0.041^{*} \\
(0.022)\end{array}$ \\
\hline Entry $A$ & $\begin{array}{r}0.035 \\
(0.0\end{array}$ & $\begin{array}{r}0.04 \\
(0.1\end{array}$ & $\begin{array}{c}0.012 \\
(0.015)\end{array}$ & & $\begin{array}{c}-0.100 * * * \\
(0.024)\end{array}$ & $\begin{array}{c}-0.094^{* * *} \\
(0.024)\end{array}$ \\
\hline Entry Age: & & & $\begin{array}{c}0.071^{* * *} \\
(0.012)\end{array}$ & $\begin{array}{c}0.048 * * * \\
(0.012)\end{array}$ & $\begin{array}{c}-0.111 * * * \\
(0.018)\end{array}$ & $\begin{array}{c}-0.108^{* * *} \\
(0.018)\end{array}$ \\
\hline Male & $\begin{array}{c}0.044 * * * \\
(0.007)\end{array}$ & $\begin{array}{r}0.04 \\
(0.1\end{array}$ & $\begin{array}{c}-0.032^{* * * *} \\
(0.008)\end{array}$ & $\begin{array}{c}-0.029^{* * *} \\
(0.008)\end{array}$ & $\begin{array}{c}-0.070^{* * * *} \\
(0.014)\end{array}$ & $\begin{array}{c}-0.070^{* * *} \\
(0.014)\end{array}$ \\
\hline $\begin{array}{r}\text { Salary } \\
(\$ 00\end{array}$ & $\begin{array}{r}-0.04 \\
(0.0\end{array}$ & $\begin{array}{r}-0.04 \\
(0.0\end{array}$ & $\begin{array}{c}0.065^{* * *} \\
(0.003)\end{array}$ & $\begin{array}{r}0.05 \\
(0.0\end{array}$ & $\begin{array}{c}0.030^{* * * *} \\
(0.004)\end{array}$ & $\begin{array}{r}0.03 \\
(0.1\end{array}$ \\
\hline $\begin{aligned} \text { Emp } \\
\text { Ed }\end{aligned}$ & $\begin{array}{r}0.04 \\
(0.0\end{array}$ & $\begin{array}{l}-0.1 \\
(0.0\end{array}$ & $\begin{array}{r}-0.16 \\
(0.0\end{array}$ & $\begin{array}{r}-0.05 \\
(0.0\end{array}$ & $\begin{array}{c}0.096^{* * * *} \\
(0.024)\end{array}$ & $\begin{array}{c}0.089 * * * \\
(0.024)\end{array}$ \\
\hline $\begin{array}{r}\text { Empl } \\
\text { Go }\end{array}$ & $\begin{array}{c}0.071^{* * *} \\
(0.011)\end{array}$ & $\begin{array}{r}0.06 \\
(0.0\end{array}$ & $\begin{array}{c}-0.105 * * * \\
(0.013)\end{array}$ & $\begin{array}{c}-0.085^{* * *} \\
(0.012)\end{array}$ & $\begin{array}{c}-0.046^{* * * *} \\
(0.018)\end{array}$ & $\begin{array}{c}-0.043^{* *} \\
(0.018)\end{array}$ \\
\hline $\begin{aligned} \text { Empl } \\
\text { Edu }\end{aligned}$ & & & $\begin{array}{c}-0.154^{* * * *} \\
(0.011)\end{array}$ & $\begin{array}{c}-0.045^{* * *} \\
(0.011)\end{array}$ & $\begin{array}{c}0.007 \\
(0.016)\end{array}$ & \\
\hline $\begin{array}{l}\text { Systen } \\
\text { Firef }\end{array}$ & $\begin{array}{c}0.049^{* * *} \\
(0.014)\end{array}$ & $\begin{array}{r}0.05 \\
(0.1\end{array}$ & $\begin{array}{l}0.036^{*} \\
(0.019)\end{array}$ & $\begin{array}{c}0.018 \\
(0.018)\end{array}$ & $\begin{array}{c}-0.116^{* * *} \\
(0.026)\end{array}$ & $\begin{array}{c}-0.105^{* * *} \\
(0.026)\end{array}$ \\
\hline Plan C & & & $\begin{array}{c}0.034 * * * \\
(0.009)\end{array}$ & $\begin{array}{c}0.035^{* * * *} \\
(0.009)\end{array}$ & $\begin{array}{c}-0.044 * * * \\
(0.016)\end{array}$ & $\begin{array}{c}-0.047^{* * *} \\
(0.016)\end{array}$ \\
\hline Plan C & $\begin{array}{l}-0.004 \\
(0.008)\end{array}$ & $\begin{array}{r}0.0 \\
(0.0\end{array}$ & $\begin{array}{c}0.071^{* * *} \\
(0.010)\end{array}$ & $\begin{array}{c}0.053^{* * *} \\
(0.010)\end{array}$ & $\begin{array}{c}-0.075^{* * *} \\
(0.016)\end{array}$ & $\begin{array}{c}-0.065^{* * *} \\
(0.016)\end{array}$ \\
\hline $\begin{array}{l}\text { Separ: } \\
\text { choi }\end{array}$ & & $\begin{array}{l}-0.006 \\
(0.009)\end{array}$ & & $\begin{array}{c}-0.075^{* * *} \\
(0.010)\end{array}$ & & $\begin{array}{c}0.141^{* * *} \\
(0.021)\end{array}$ \\
\hline $\begin{array}{l}\text { Contributed to Suppl. Plan } \\
\text { in plan choice year }\end{array}$ & & $\begin{array}{c}-0.175^{* * *} \\
(0.010)\end{array}$ & & $\begin{array}{c}0.389 * * * \\
(0.009)\end{array}$ & & $\begin{array}{l}-0.012 \\
(0.014)\end{array}$ \\
\hline & & & & & & \\
\hline & & & & & & \\
\hline Mean & 0. & 0.799 & 0.421 & 0.421 & 0.477 & 0.477 \\
\hline
\end{tabular}

*** $\mathrm{p}<0.01,{ }^{* *} \mathrm{p}<0.05,{ }^{*} \mathrm{p}<0.1$

Separation data incomplete for individuals hired after September 30, 2012.

Constant term also included. Reference categories: Entry Age 25-29; Employer State Government;

System Public Employees; Plan Choice Year 2012. 
Table 5. Supplemental Retirement Plan Participation Rates with Mean Contribution Rates Shown in Italics

\begin{tabular}{|c|c|c|c|c|c|c|c|c|c|c|c|c|}
\hline \multirow{3}{*}{ Entry Year } & \multicolumn{4}{|c|}{ All } & \multicolumn{4}{|c|}{ Hired Post-Reform } & \multicolumn{4}{|c|}{ Made Active Choice } \\
\hline & \multicolumn{2}{|c|}{ Pre-Reform } & \multicolumn{2}{|c|}{ Post-Reform } & \multicolumn{2}{|c|}{$\begin{array}{l}\text { Made Active } \\
\text { Choice }\end{array}$} & \multicolumn{2}{|c|}{$\begin{array}{c}\text { Defaulted into } \\
\text { Hybrid }\end{array}$} & \multicolumn{2}{|c|}{ Chose Hybrid } & \multicolumn{2}{|c|}{ Chose DC } \\
\hline & & & & & & & & & & & & \\
\hline 2006 & 46.8 & 4.7 & & . & . & . & & . & . & . & . & . \\
\hline 2007 & 44.0 & 4.5 & & . & . & . & . & . & . & . & . & . \\
\hline 2008 & 39.7 & 4.4 & . & . & . & . & 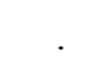 & . & . & . & . & . \\
\hline 2009 & 25.7 & 4.4 & . & . & . & . & . & . & . & . & . & . \\
\hline 2010 & 24.1 & 4.2 & . & . & . & . & 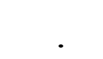 & . & . & . & . & . \\
\hline 2011 & 26.7 & 4.3 & . & . & . & . & . & . & . & . & . & . \\
\hline 2012 & . & . & 17.8 & 4.5 & 34.0 & 4.7 & 7.3 & 4.2 & 33.6 & 4.5 & 34.4 & 4.8 \\
\hline 2013 & . & . & 19.7 & 4.2 & 36.3 & 4.4 & 7.2 & 3.3 & 38.3 & 4.1 & 33.8 & 5.0 \\
\hline 2014 & . & . & 15.9 & 4.5 & 29.0 & 4.6 & 4.8 & 3.6 & 32.6 & 4.1 & 24.8 & 5.5 \\
\hline \multicolumn{13}{|l|}{ Plan Type } \\
\hline All Plans & 34.5 & 4.4 & 18.2 & 4.4 & 33.9 & 4.6 & 6.8 & 3.8 & 35.5 & 4.2 & 32.3 & 5.0 \\
\hline $401(\mathrm{k})$ & 29.7 & 4.0 & 15.2 & 3.8 & 28.2 & 3.9 & 5.8 & 3.3 & 29.2 & 3.7 & 27.1 & 4.2 \\
\hline 457 & 6.7 & 3.9 & 2.4 & 4.2 & 4.4 & 4.5 & 1.0 & 3.5 & 4.8 & 3.4 & 3.9 & 5.9 \\
\hline IRA & 1.8 & 3.4 & 3.5 & 3.4 & 7.4 & 3.4 & 0.7 & 3.9 & 8.5 & 3.1 & 6.2 & 3.8 \\
\hline Multiple & 3.6 & 6.5 & 2.7 & 7.2 & 5.5 & 7.3 & 0.7 & 6.8 & 6.2 & 6.9 & 4.7 & 7.9 \\
\hline
\end{tabular}

Note: The table shows the percentage of employees in each group who contributed to one of the Utah Retirement Systems (URS) supplemental retirement savings plans in the calendar year following the year of hire. The average total contribution to all Utah Retirement Systems (URS) supplemental retirement savings plans in the calendar year following the year of hire as a percentage of annual salary for participants is shown in italics. Participants who were reported to have contributed more than the maximum amount allowed by the Internal Revenue based on their age and salary are excluded $(\mathrm{n}=55)$. The pre-reform group includes individuals hired before July 1, 2011 who were automatically enrolled in a traditional defined benefit plan. The post-reform group includes individuals hired on or after July 1, 2011 who were given the choice between a defined contribution (DC) plan and a hybrid plan. Plan choice elections become final at the end of the first year of employment. Individuals in the post-reform group who did not make an active election during the first year were defaulted into the hybrid plan. The fiscal year ending June 30 , 2006 only includes individuals hired during the six-month period beginning January 1, 2006. The fiscal year ending June 30, 2014 only includes individuals hired during the three-month period ending September 30, 2013 
Table 6. Multivariate Estimates of Determinants of Participation in and Contributions to Supplemental Retirement Plans (OLS, standard errors in parentheses)

\begin{tabular}{|c|c|c|c|c|}
\hline \multirow[b]{3}{*}{ Independent Variable } & \multicolumn{4}{|c|}{ Dependent Variable } \\
\hline & \multicolumn{2}{|c|}{ Contributed to Suppl. Plan } & \multicolumn{2}{|c|}{ Suppl. Plan Contribution Rate } \\
\hline & $\begin{array}{l}\text { All Post- } \\
\text { Reform } \\
(1)\end{array}$ & $\begin{array}{c}\text { Only State } \\
\text { Government } \\
(2)\end{array}$ & $\begin{array}{l}\text { All Post- } \\
\text { Reform } \\
(3)\end{array}$ & $\begin{array}{c}\text { Only State } \\
\text { Government } \\
(4)\end{array}$ \\
\hline \multirow[t]{2}{*}{ Plan Choice: Chose DC } & $0.216 * * *$ & $0.451 * * *$ & $1.119 * * *$ & $1.090 * *$ \\
\hline & $(0.007)$ & $(0.021)$ & $(0.282)$ & $(0.477)$ \\
\hline \multirow[t]{2}{*}{ Plan Choice: Chose Hybrid } & $0.231 * * *$ & $0.414 * * *$ & $0.455^{*}$ & 0.423 \\
\hline & $(0.007)$ & $(0.020)$ & $(0.269)$ & $(0.473)$ \\
\hline \multirow[t]{2}{*}{ Entry Age: Under 25} & 0.004 & -0.033 & -0.214 & -0.428 \\
\hline & $(0.008)$ & $(0.025)$ & $(0.311)$ & $(0.495)$ \\
\hline \multirow[t]{2}{*}{ Entry Age: 30 - 34} & 0.009 & -0.032 & -0.222 & -0.098 \\
\hline & $(0.009)$ & $(0.025)$ & $(0.318)$ & $(0.456)$ \\
\hline \multirow[t]{2}{*}{ Entry Age: 35 - 39} & 0.003 & -0.036 & -0.476 & -0.501 \\
\hline & $(0.010)$ & $(0.029)$ & $(0.373)$ & $(0.536)$ \\
\hline \multirow{2}{*}{ Entry Age: 40 - 44} & $0.036^{* * *}$ & 0.042 & $0.843 * *$ & 0.553 \\
\hline & $(0.011)$ & $(0.034)$ & $(0.392)$ & $(0.581)$ \\
\hline \multirow[t]{2}{*}{ Entry Age: 45 and Above } & $0.033 * * *$ & 0.042 & $1.659 * * *$ & $0.864^{*}$ \\
\hline & $(0.009)$ & $(0.026)$ & $(0.315)$ & $(0.450)$ \\
\hline \multirow[t]{2}{*}{ Male } & -0.004 & $-0.040 * *$ & -0.321 & $-0.804 * *$ \\
\hline & $(0.006)$ & $(0.018)$ & $(0.222)$ & $(0.324)$ \\
\hline \multirow[t]{2}{*}{ Salary in plan choice year $(\$ 000)$} & $0.011 * * *$ & $0.043 * * *$ & $-1.636^{* *}$ & -0.709 \\
\hline & $(0.004)$ & $(0.013)$ & $(0.717)$ & $(1.275)$ \\
\hline \multirow[t]{2}{*}{ Salary $^{2}$} & -0.000 & $-0.002 * *$ & $0.337 * *$ & 0.154 \\
\hline & $(0.000)$ & $(0.001)$ & $(0.167)$ & $(0.266)$ \\
\hline \multirow[t]{2}{*}{ Salary $^{3}$} & & & -0.021 & -0.003 \\
\hline & & & $(0.014)$ & $(0.021)$ \\
\hline \multirow[t]{2}{*}{ Salary ${ }^{4}$} & & & 0.000 & -0.000 \\
\hline & & & $(0.000)$ & $(0.001)$ \\
\hline \multirow[t]{2}{*}{ Employer: Higher Education } & $-0.242 * * *$ & & 0.486 & \\
\hline & $(0.011)$ & & $(0.484)$ & \\
\hline \multirow{2}{*}{ Employer: Local Government } & $-0.036 * * *$ & & $0.617 * *$ & \\
\hline & $(0.009)$ & & $(0.243)$ & \\
\hline \multirow[t]{2}{*}{ Employer: Public Education } & $-0.252 * * *$ & & $1.400 * * *$ & \\
\hline & $(0.008)$ & & $(0.286)$ & \\
\hline System: Public Safety \& & 0.021 & 0.012 & 0.306 & 0.252 \\
\hline Firefighters & $(0.013)$ & $(0.030)$ & $(0.356)$ & $(0.556)$ \\
\hline Observations & 16,095 & 2,711 & 2,912 & 1,045 \\
\hline R-squared & 0.213 & 0.251 & 0.057 & 0.083 \\
\hline Mean & 0.182 & 0.388 & 4.381 & 3.952 \\
\hline
\end{tabular}

$* * * \mathrm{p}<0.01,{ }^{* *} \mathrm{p}<0.05,{ }^{*} \mathrm{p}<0.1$

Constant term and plan choice year also included. Reference categories: Plan Choice Defaulted into Hybrid; Entry Age 25-29; Employer State Government; System Public Employees; Choice Year 2012. 
Table 7. Second Year Retention Rates

\begin{tabular}{|c|c|c|c|c|c|c|c|c|}
\hline \multirow{2}{*}{\multicolumn{2}{|c|}{ Entry Date }} & \multicolumn{2}{|c|}{ All } & \multicolumn{2}{|c|}{ Hired Post-Reform } & \multicolumn{2}{|c|}{ Made Active Choice } & \multirow[b]{2}{*}{ Observations } \\
\hline & & $\begin{array}{l}\text { Pre- } \\
\text { Reform }\end{array}$ & $\begin{array}{l}\text { Post- } \\
\text { Reform }\end{array}$ & $\begin{array}{l}\text { Made } \\
\text { Active } \\
\text { Choice }\end{array}$ & $\begin{array}{c}\text { Defaulted } \\
\text { into } \\
\text { Hybrid } \\
\end{array}$ & $\begin{array}{l}\text { Chose } \\
\text { Hybrid }\end{array}$ & $\begin{array}{c}\text { Chose } \\
\text { DC }\end{array}$ & \\
\hline \multicolumn{9}{|c|}{ Fiscal Year Ending } \\
\hline June 30, & 2006 & 86.9 & . & . & . & . & . & 2,708 \\
\hline & 2007 & 87.0 & . & . & . & . & $\cdot$ & 8,537 \\
\hline & 2008 & 87.9 & . & $\cdot$ & . & . & . & 8,913 \\
\hline & 2009 & 86.7 & $\cdot$ & $\cdot$ & 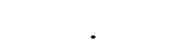 & . & $\cdot$ & 6,890 \\
\hline & 2010 & 86.2 & . & . & 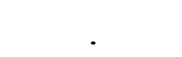 & . & . & 5,323 \\
\hline & 2011 & 87.1 & . & . & $\cdot$ & . & . & 5,807 \\
\hline & 2012 & . & 83.5 & 88.3 & 80.3 & 91.1 & 85.7 & 6,333 \\
\hline & 2013 & . & 81.4 & 85.8 & 78.6 & 90.7 & 80.8 & 3,388 \\
\hline All & & 87.1 & 82.8 & 87.5 & 79.7 & 91.0 & 84.1 & 47,899 \\
\hline
\end{tabular}

Note: The table shows the percentage of employees in each group who remained employed by Utah Retirement System covered employer for at least two years. Employees who first entered employment with a Utah Retirement System covered employer between January 1, 2006 and September 30, 2012 and did not separate from employment during the first 12 months are included. Therefore, this table reflects retention rates during the second year of employment, given that an individual remained employed through the first year. For example, an individual hired February 1, 2012 is not included in the table unless he or she remained employed through February 1, 2013, and is not counted as remaining for at least two years if he or she separated from employment prior to February 1, 2014. Individuals who terminated employment due to death or disability are not included $(n=43)$.

The pre-reform group includes individuals hired before July 1, 2011 who were automatically enrolled in a traditional defined benefit plan. The post-reform group includes individuals hired on or after July 1, 2011 who were given the choice between a defined contribution (DC) plan and a hybrid plan. Plan choice elections become final at the end of the first year of employment. Individuals in the post-reform group who did not make an active election during the first year were defaulted into the hybrid plan. The fiscal year ending June 30, 2006 only includes individuals hired during the six-month period beginning January 1, 2006. The fiscal year ending June 30, 2013 only includes individuals hired during the three-month period ending September 30, 2012. 
Table 8. Multivariate Estimates of Determinants of Second-Year Retention (OLS, robust standard errors in parentheses)

\begin{tabular}{|c|c|c|c|}
\hline \multirow[b]{2}{*}{ Independent Variable } & \multicolumn{3}{|c|}{ Dependent Variable: Remain in second year } \\
\hline & $\begin{array}{c}\text { Post-Reform } \\
\text { (1) }\end{array}$ & $\begin{array}{l}\text { All } \\
(2)\end{array}$ & $\begin{array}{c}\text { Hired 7/2010- } \\
6 / 2012 \\
(3) \\
\end{array}$ \\
\hline Plan Choice: Chose DC & $\begin{array}{c}0.023 * * \\
(0.010)\end{array}$ & & \\
\hline Plan Choice: Chose Hybrid & $\begin{array}{c}0.081 * * * \\
(0.009)\end{array}$ & & \\
\hline Post-Reform & & $\begin{array}{c}-0.037 * * * \\
(0.004)\end{array}$ & $\begin{array}{c}-0.028 * * * \\
(0.006)\end{array}$ \\
\hline Entry Age: Under 25 & $\begin{array}{c}-0.035^{* * *} \\
(0.011)\end{array}$ & $\begin{array}{c}-0.031 * * * \\
(0.005)\end{array}$ & $\begin{array}{c}-0.032 * * * \\
(0.010)\end{array}$ \\
\hline Entry Age: 30 - 34 & $\begin{array}{c}-0.004 \\
(0.013)\end{array}$ & $\begin{array}{c}0.018 * * * \\
(0.005)\end{array}$ & $\begin{array}{c}0.021 * * \\
(0.010)\end{array}$ \\
\hline Entry Age: 35 - 39 & $\begin{array}{c}0.025^{*} \\
(0.013)\end{array}$ & $\begin{array}{c}0.041 * * * \\
(0.006)\end{array}$ & $\begin{array}{c}0.037 * * * \\
(0.011)\end{array}$ \\
\hline Entry Age: $40-44$ & $\begin{array}{c}0.039 * * * \\
(0.014)\end{array}$ & $\begin{array}{c}0.058 * * * \\
(0.006)\end{array}$ & $\begin{array}{c}0.072 * * * \\
(0.011)\end{array}$ \\
\hline Entry Age: 45 and Above & $\begin{array}{c}0.042 * * * \\
(0.012)\end{array}$ & $\begin{array}{c}0.053 * * * \\
(0.005)\end{array}$ & $\begin{array}{c}0.052 * * * \\
(0.010)\end{array}$ \\
\hline Male & $\begin{array}{c}0.016^{*} \\
(0.008)\end{array}$ & $\begin{array}{c}0.017 * * * \\
(0.004)\end{array}$ & $\begin{array}{c}0.012 \\
(0.007)\end{array}$ \\
\hline Salary in plan choice year $(\$ 000)$ & $\begin{array}{c}0.032 * * * \\
(0.003)\end{array}$ & $\begin{array}{c}0.021 * * * \\
(0.001)\end{array}$ & $\begin{array}{c}0.028 * * * \\
(0.002)\end{array}$ \\
\hline Employer: Higher Education & $\begin{array}{c}0.001 \\
(0.017)\end{array}$ & $\begin{array}{c}-0.037 * * * \\
(0.007)\end{array}$ & $\begin{array}{c}-0.040 * * * \\
(0.013)\end{array}$ \\
\hline Employer: Local Government & $\begin{array}{c}0.061 * * * \\
(0.013)\end{array}$ & $\begin{array}{c}0.024 * * * \\
(0.005)\end{array}$ & $\begin{array}{c}0.033 * * * \\
(0.009)\end{array}$ \\
\hline Employer: Public Education & $\begin{array}{c}0.051 * * * \\
(0.012)\end{array}$ & $\begin{array}{c}0.025 * * * \\
(0.005)\end{array}$ & $\begin{array}{c}0.035 * * * \\
(0.009)\end{array}$ \\
\hline System: Public Safety \& Firefighters & $\begin{array}{c}0.109 * * * \\
(0.012)\end{array}$ & $\begin{array}{c}0.087 * * * \\
(0.005)\end{array}$ & $\begin{array}{c}0.096 * * * \\
(0.009)\end{array}$ \\
\hline Plan Choice Year: 2013 & $\begin{array}{c}-0.027 * * * \\
(0.008)\end{array}$ & & \\
\hline Plan Choice Year: 2014 & $\begin{array}{c}-0.186^{* * *} \\
(0.072)\end{array}$ & & \\
\hline Observations & 9,721 & 47,899 & 12,140 \\
\hline R-squared & 0.045 & 0.031 & 0.040 \\
\hline Mean & 0.828 & 0.862 & 0.852 \\
\hline
\end{tabular}


Figure 1. Changes under Utah's Public Pension Reform

\begin{tabular}{|c|l|}
\hline Choice of Default Plan & $\begin{array}{l}\text { 60 percent of new hires failed to make an active choice of } \\
\text { their retirement plan. } \\
\text { Young employees who might be better served by the DC plan } \\
\text { were more likely to default into the hybrid plan. }\end{array}$ \\
\hline $\begin{array}{c}\text { Supplemental } \\
\text { Retirement Savings }\end{array}$ & $\begin{array}{l}\text { Despite lower expected benefits from pension, fewer new } \\
\text { employees contributed to a supplemental saving plan. } \\
\text { Defaulters much less likely to contribute to a saving plan; } \\
\text { participation rate } 30 \text { percentage points lower. }\end{array}$ \\
\hline Turnover Rates & $\begin{array}{l}\text { Employees covered by less generous retirement benefits more } \\
\text { likely to leave public employment. }\end{array}$ \\
\hline
\end{tabular}

Source: See text. 
Figure 2. Patterns of Supplemental Retirement Plan Participation

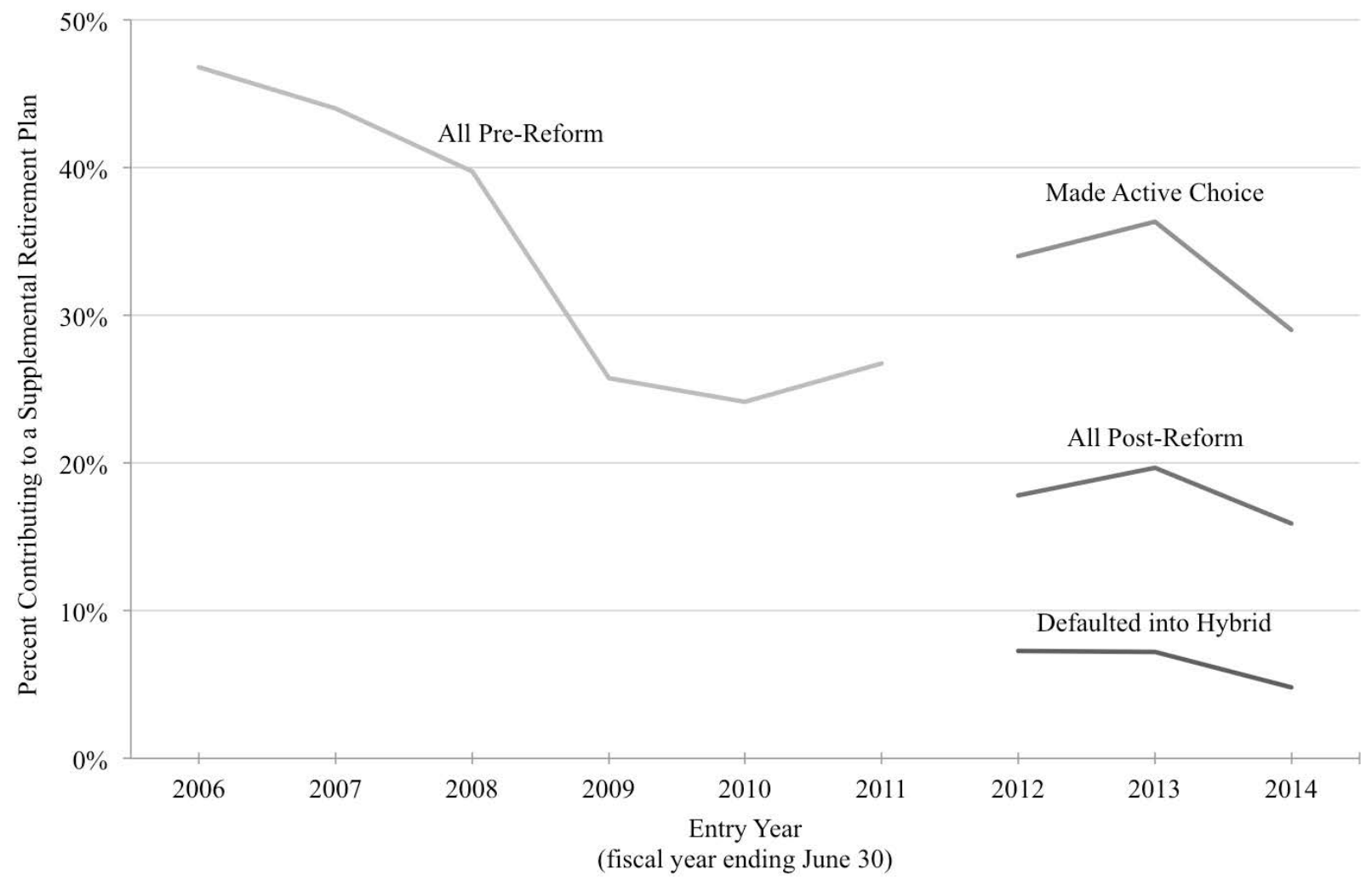

Source: Authors' analysis of URS data (see text). 
Figure 3. Second-Year Separation Rates

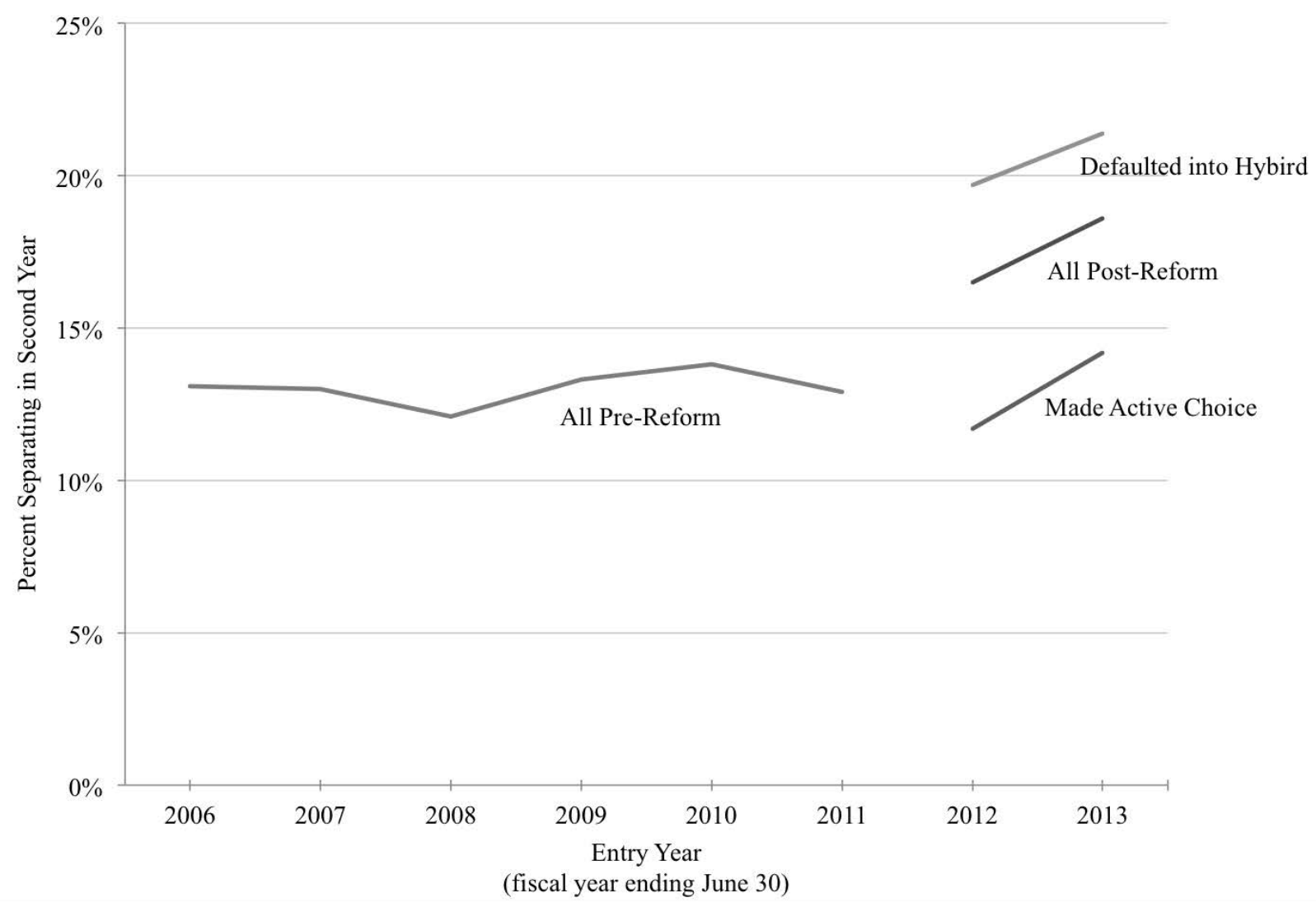

Source: Authors' analysis of URS data (see text). 
Figure 4. Second Year Retention Rates
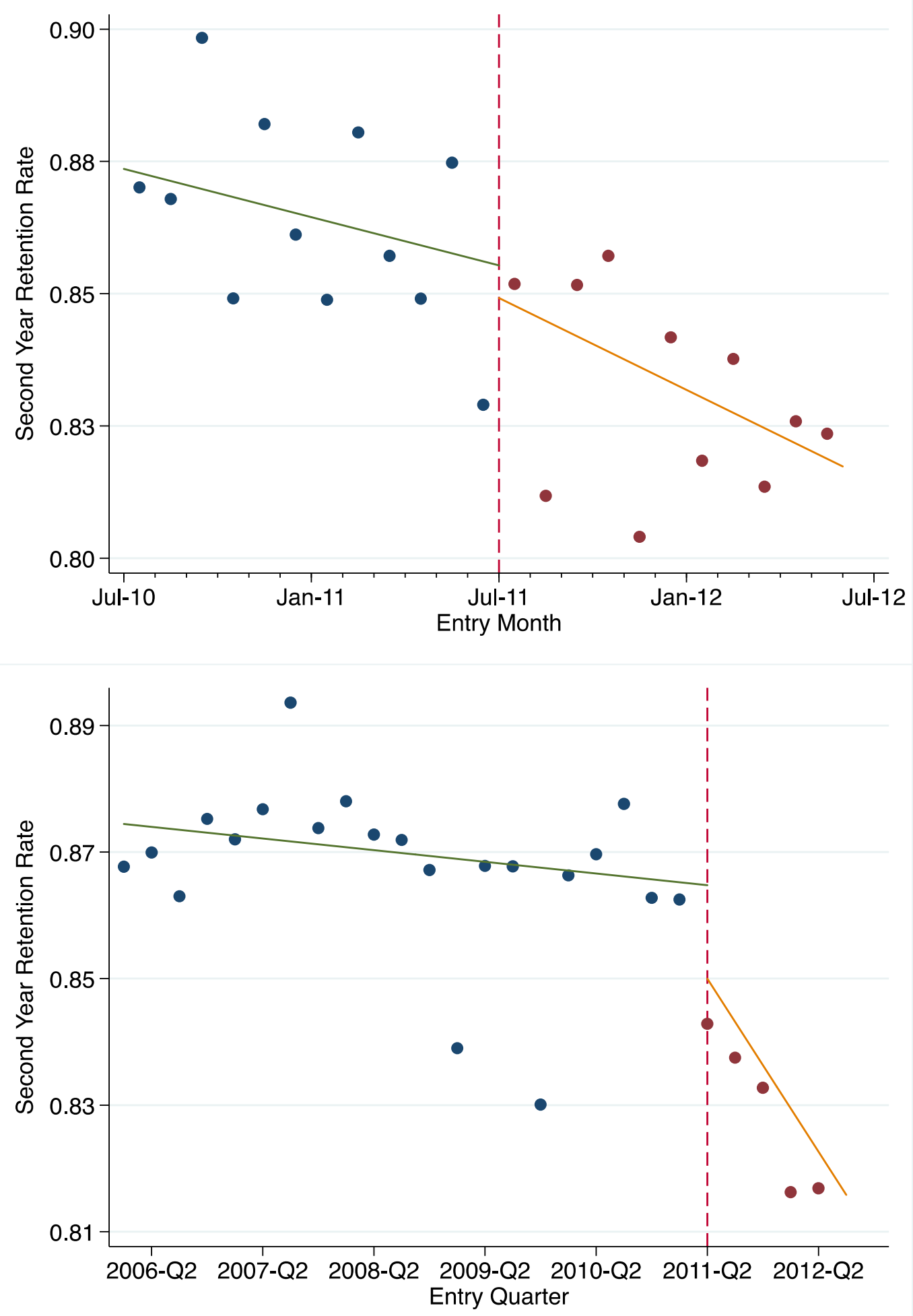

Source: Authors' analysis of URS data (see text) 


\begin{tabular}{|c|c|c|c|c|c|c|c|}
\hline & \multicolumn{3}{|c|}{ Tier I } & \multicolumn{4}{|c|}{ Tier II } \\
\hline Description & \multicolumn{3}{|c|}{$\begin{array}{l}\text { A person entering full-time employments with a } \\
\text { participating employer before July } 1,2011 \text { is a } \\
\text { member of the Tier I system. The Contributory } \\
\text { System was closed to new employees of the State } \\
\text { and its Education institutions on July 1, 1986; a } \\
\text { few Local Governmental employers continue to } \\
\text { enroll new employees in this system. }\end{array}$} & \multicolumn{4}{|c|}{$\begin{array}{l}\text { A person entering full-time employment with a participating employer on or } \\
\text { after July 1, 2011 who does not have service credit in a Tier I system must make } \\
\text { an election to participate in either the Hybrid System or the Defined Contribution } \\
\text { (DC) Plan, within one year of his/her employment date. The election made is } \\
\text { irrevocable. If no election is made, the employee automatically becomes a } \\
\text { member of the Hybrid System. }\end{array}$} \\
\hline $\begin{array}{l}\text { Retirement } \\
\text { System }\end{array}$ & $\begin{array}{l}\text { Public } \\
\text { Employees } \\
\text { Contributory }\end{array}$ & $\begin{array}{l}\text { Public } \\
\text { Employees } \\
\text { Noncontributory }\end{array}$ & \begin{tabular}{|l|} 
Public Safety/ \\
Firefighters
\end{tabular} & $\begin{array}{l}\text { Public Employees } \\
\text { (Hybrid) }\end{array}$ & $\begin{array}{l}\text { Public Employees } \\
\text { (DC) }\end{array}$ & $\begin{array}{l}\text { Public Safety/ } \\
\text { Firefighters } \\
\text { (Hybrid) }\end{array}$ & $\begin{array}{l}\text { Public Safety/ } \\
\text { Firefighters } \\
\text { (DC) }\end{array}$ \\
\hline $\begin{array}{l}\text { Qualifications } \\
\text { (years/age) }\end{array}$ & $\begin{array}{l}30 \text { yrs any age } \\
20 \text { yrs age } 60^{\wedge} \\
10 \text { yrs age } 62^{\wedge} \\
4 \text { yrs age } 65\end{array}$ & $\begin{array}{l}30 \text { yrs any age } \\
25 \text { yrs any age } \\
20 \text { yrs age } 60 \wedge \\
10 \text { yrs age } 62^{\wedge} \\
4 \text { yrs age } 65\end{array}$ & $\begin{array}{l}20 \text { yrs any age } \\
10 \text { yrs age } 60 \\
4 \text { yrs age } 65\end{array}$ & $\begin{array}{l}35 \text { yrs any age } 20 \\
\text { yrs age } 60 \\
10 \text { yrs age } 62 \\
4 \text { yrs age } 65\end{array}$ & $\begin{array}{l}\text { Members will have } \\
\text { access to the full } \\
\text { value of their } \\
\text { vested account } \\
\text { balance when they } \\
\text { leave }\end{array}$ & $\begin{array}{l}25 \text { yrs any age } 20 \\
\text { yrs age } 60 \\
10 \text { yrs age } 62 \\
4 \text { yrs age } 65\end{array}$ & $\begin{array}{l}\text { Members will have } \\
\text { access to the full } \\
\text { value of their vested } \\
\text { account balance } \\
\text { when they leave } \\
\text { e mployment. }\end{array}$ \\
\hline Formula & $\begin{array}{l}1.25 \text { per yr to } \\
6 / 30 / 1975 \\
2 \text { per yr } \\
7 / 1 / 1975 \text { to } \\
\text { present }\end{array}$ & 2 per yr all years & $\begin{array}{l}2.5 \text { per yr up to } \\
20 \text { yrs } \\
2 \text { per yr over } 20 \\
\text { yrs }\end{array}$ & $\begin{array}{l}1.5 \text { per yr of service } \\
\text { credit \& } 401(\mathrm{k}) \\
\text { contribution (Equal } \\
\text { to } 10 \text { minus the } \\
\text { Hybrid DB Plan } \\
\text { Rate) }\end{array}$ & $\begin{array}{l}\text { Employer } \\
\text { contributes } 10 \text { to } \\
\text { member } 401(\mathrm{k}) \\
\text { plan. Benefit is not } \\
\text { based on a fixed } \\
\text { formula. }\end{array}$ & $\begin{array}{l}1.5 \text { per yr of service } \\
\text { credit \& } 401(\mathrm{k}) \\
\text { contribution (Equal } \\
\text { to } 12 \text { minus the } \\
\text { Hybrid DB Plan } \\
\text { Rate) } \\
\end{array}$ & $\begin{array}{l}\text { Employer } \\
\text { contributes } 12 \text { to } \\
\text { member } 401(\mathrm{k}) \\
\text { plan. Benefit is not } \\
\text { based on a fixed } \\
\text { formula. }\end{array}$ \\
\hline $\begin{array}{l}\text { Final Average } \\
\text { Salary }\end{array}$ & Highest 5 yrs & Highest 3 yrs & Highest 3 yrs & Highest 5 yrs & Not applicable & Highest 5 yrs & Not applicable \\
\hline $\begin{array}{l}\text { Cost-of- } \\
\text { Living (max) }\end{array}$ & $4^{\#}$ & $4^{\#}$ & $\begin{array}{l}\text { Public Safety: } \\
2.5^{\#} \\
\text { Firefighters: } 4^{\#}\end{array}$ & $2.5^{\#}$ & None & $2.5^{\#}$ & None \\
\hline
\end{tabular}

${ }^{\lambda}$ Early retirement benefit calculated with actuarial reduction.

\#Eligible after one year; percentage increase based on original benefit and change in CPI. Effective July 1, 2008, Tier I Public safety employers have the option to raise COLA from 2.5 to 4.

Source: Adapted by authors from Employer's Guide to the Utah Retirement Systems

https://www.urs.org/mango/pdf/urs/Miscellaneous/employerGuide.pdf 


\section{Appendix Table 2. Data Construction and Variable Description}

\begin{tabular}{|c|c|c|c|c|c|c|c|c|}
\hline & \multirow{2}{*}{$\begin{array}{c}\text { All } \\
\text { Pre- } \\
\text { reform } \\
\end{array}$} & \multicolumn{4}{|c|}{ Post-reform } & \multirow[b]{2}{*}{ Pending } & \multirow[b]{2}{*}{ All } \\
\hline & & & $\begin{array}{l}\text { All Post- } \\
\text { Reform }\end{array}$ & $\begin{array}{l}\text { Defaulted } \\
\text { into Hybrid }\end{array}$ & $\begin{array}{l}\text { Chose } \\
\text { Hybrid }\end{array}$ & $\mathrm{DC}$ & & \\
\hline$(1)$ & Individuals in original file & 53,725 & 29,358 & 13,249 & 3,959 & 3,772 & 8,378 & 83,083 \\
\hline (2) & $\begin{array}{l}\text { With some non-missing annual } \\
\text { data }\end{array}$ & 48,439 & 28,324 & 12,929 & 3,948 & 3,616 & 7,831 & 76,763 \\
\hline (3) & $\begin{array}{l}\text { Entered URS between } 1 / 1 / 2006 \\
\text { and } 9 / 30 / 2013\end{array}$ & 48,389 & 20,107 & 12,652 & 3,840 & 3,603 & 12 & 68,496 \\
\hline (4) & No Judicial or Legislative service & 48,353 & 20,106 & 12,652 & 3,840 & 3,602 & 12 & 68,459 \\
\hline (5) & No previous URS employment & 47,924 & 20,072 & 12,633 & 3,837 & 3,591 & 11 & 67,996 \\
\hline (6) & $\begin{array}{l}\text { Did not separate from employment } \\
\text { during the first } 12 \text { months }\end{array}$ & 39,154 & 16,263 & 9,448 & 3,553 & 3,262 & 0 & 55,417 \\
\hline (7) & $\begin{array}{l}\text { Annualized salary available in year } \\
\text { of plan choice or year following } \\
\text { plan choice. }\end{array}$ & 38,321 & 16,095 & 9,321 & 3,540 & 3,234 & 0 & 54,321 \\
\hline$(8)$ & Age and gender available & 38,220 & 16,095 & 9,321 & 3,540 & 3,234 & & 54,315 \\
\hline (9) & Entered URS before 9/30/2012 & 38,220 & 9,721 & 5,893 & 1,881 & 1,947 & 0 & 47,942 \\
\hline$(10)$ & $\begin{array}{l}\text { Did not separate due to death or } \\
\text { disability }\end{array}$ & 38,136 & 9,720 & 5,893 & 1,881 & 1,947 & 0 & 47,899 \\
\hline
\end{tabular}

We use the data set in row 8 for all analysis except the analysis of retention rates for which we use the data set in row 10. In the analysis of supplemental plan contributions, 55 participants who were reported to have contributed more than the maximum amount allowed by the Internal Revenue based on their age and salary are excluded.

\section{Variables}

Entry year: The fiscal year ending June 30 during which the individual was first hired into an eligible position by a Utah Retirement System covered employer

Plan choice year: The first calendar year after the entry year in which the individual earned at least .0417 years of service credit. For individuals hired after July 1, 2011, this is the calendar year that includes the date when their plan choice became final, or the year immediately following that year, if they first hired near the end of the year.

Entry age: Approximate age of employee when they first became a member of one of the plans administered by the Utah Retirement System.

Salary in plan choice year: Employee earning in the plan choice year in 2014 dollars. If less than one year of service was reported, earnings are annualized by dividing total salary by total reported service.

Employer: The classification of the employer where the individual worked most during the calendar year in which plan choice became final. State Government includes quasi-state agencies and independent agencies.

System: The pension system in which the individual earned the most service credit during the calendar year in which plan choice became final.

Separated in second year: Indicator for an individual separating from employment within the first 24 months, based on separations reported before November 1, 2014.

Contributed to SRP in plan choice year: Indicator for an individual making a contribution of any amount to at least one of the four Supplemental Retirement Plans (SRPs) offered by URS. 
Appendix Table 3. Probit Estimates of Plan Choice: Marginal Effects (standard errors in parentheses)

\begin{tabular}{|c|c|c|c|c|c|c|}
\hline \multirow[b]{3}{*}{ Independent Variable } & \multicolumn{6}{|c|}{ Dependent Variable } \\
\hline & \multicolumn{2}{|c|}{$\begin{array}{c}\text { Hybrid } \\
\text { (by default or choice) }\end{array}$} & \multicolumn{2}{|c|}{ Any Active Choice } & \multicolumn{2}{|c|}{$\begin{array}{c}\text { Choose DC } \\
\text { (given active choice) }\end{array}$} \\
\hline & & $(2)$ & (3) & (4) & $(5)$ & $(6)$ \\
\hline \multirow[t]{2}{*}{ Entry Age: Under 25} & & & -0.0 & -0.0 & & \\
\hline & & & $(0$. & & & \\
\hline \multirow[t]{2}{*}{ Entry Age: 30 - 34} & & & & & $-0.043 * *$ & -0.0 \\
\hline & & & $(0.0$ & $(0$. & 20) & \\
\hline \multirow[t]{2}{*}{ Entry Age: 35 - 39} & & & & & $43^{*}$ & -0 . \\
\hline & & & $(0.1$ & & 22) & \\
\hline \multirow[t]{2}{*}{ Entry Age: 40 - 44} & $* *$ & & & & $9 * * *$ & -0.0 \\
\hline & & & $(0$. & $(0$. & 24) & \\
\hline \multirow[t]{2}{*}{ Entry Age: 45 and Above } & & & 0.07 & $* * *$ & $0 * * *$ & -0.1 \\
\hline & & & $(0.012)$ & $(0$. & $(0.018)$ & $(0$ \\
\hline \multirow[t]{2}{*}{ Male } & $* * *$ & 0.0 & -0.0 & -0.03 & $0 * * *$ & -0.0 \\
\hline & $(0$ & & $(0$. & $(0$. & 14) & \\
\hline \multirow{2}{*}{$\begin{array}{l}\text { Salary in plan choice year } \\
(\$ 000)\end{array}$} & -0.04 & -0.0 & 0.06 & $* * *$ & $* * *$ & 0.0 \\
\hline & & & $(0$. & & & \\
\hline \multirow{2}{*}{$\begin{array}{l}\text { Employer: Higher } \\
\text { Education }\end{array}$} & & & -0.1 & $-0.058 * * *$ & $5 * * *$ & 0.0 \\
\hline & & & & & & \\
\hline \multirow{2}{*}{$\begin{array}{l}\text { Employer: Local } \\
\text { Government }\end{array}$} & 0.06 & 0.05 & $-0.105 * * *$ & $-0.092 * * *$ & $-0.046 * * *$ & -0.0 \\
\hline & & & & & & \\
\hline \multirow{2}{*}{$\begin{array}{l}\text { Employer: Public } \\
\text { Education }\end{array}$} & 0.06 & & $-0.153 * * *$ & $-0.050 * * *$ & 7 & 0. \\
\hline & & & $(0)$ & & & $(0$ \\
\hline \multirow{2}{*}{$\begin{array}{l}\text { System: Public Safety \& } \\
\text { Firefighters }\end{array}$} & $0.041 * * *$ & 0.04 & $3^{*}$ & 0.015 & $-0.117 * * *$ & $-0.105 * * *$ \\
\hline & & & & & & \\
\hline \multirow[t]{2}{*}{ Plan Choice Year: 2013} & $-\mathrm{C}$ & -0 & $0.034 * * *$ & $0.035 * * *$ & $-0.044 * * *$ & $-0.047 * * *$ \\
\hline & & & & & & \\
\hline \multirow[t]{2}{*}{ Plan Choice Year: 2014} & -0.005 & -0.001 & $0.071 * * *$ & $0.053 * * *$ & $-0.075 * * *$ & $-0.065 * * *$ \\
\hline & & & & & $(0.016)$ & \\
\hline \multirow{2}{*}{$\begin{array}{l}\text { Separated year after plan } \\
\text { choice }\end{array}$} & & -0.003 & & $-0.076^{* * *}$ & & $0.140 * * *$ \\
\hline & & & & & & \\
\hline \multirow{2}{*}{$\begin{array}{l}\text { Contributed to Suppl. Plan } \\
\text { in plan choice year }\end{array}$} & & $-0.173 * * *$ & & $0.395 * * *$ & & -0.011 \\
\hline & & & & & & \\
\hline Observations & 16,095 & 16,095 & 16,095 & 16,095 & 6,773 & 6,773 \\
\hline & -7802.185 & -7622.292 & -10301.082 & -9575.818 & -4566.354 & -4543.456 \\
\hline D & & & & 0.126 & 0.026 & 0.031 \\
\hline Mean & 0.799 & 0.799 & 0.421 & 0.421 & 0.477 & 0.477 \\
\hline
\end{tabular}

$* * * \mathrm{p}<0.01, * * \mathrm{p}<0.05, * \mathrm{p}<0.1$

Separation data incomplete for individuals hired after September 30, 2012.

Constant term also included. Reference categories: Entry Age 25-29; Employer State Government;

System Public Employees; Plan Choice Year 2012. 
Appendix Table 4. Probit Estimates of Participation in Supplemental Retirement Plans:

Marginal Effects (standard errors in parentheses)

\begin{tabular}{|c|c|c|}
\hline \multirow[b]{2}{*}{ Independent Variable } & \multicolumn{2}{|c|}{$\begin{array}{c}\text { Dependent Variable: } \\
\text { Contributed to Supplemental Retirement Plan }\end{array}$} \\
\hline & $\begin{array}{c}\text { All Post-Reform } \\
(1)\end{array}$ & $\begin{array}{c}\text { Only State Government } \\
\text { (2) }\end{array}$ \\
\hline Plan Choice: Chose DC & $\begin{array}{l}0.216^{* * * *} \\
(0.008)\end{array}$ & $\begin{array}{l}0.454 * * * \\
(0.021)\end{array}$ \\
\hline Plan Choice: Chose Hybrid & $\begin{array}{c}0.223 * * * \\
(0.008)\end{array}$ & $\begin{array}{l}0.416^{* * *} \\
(0.020)\end{array}$ \\
\hline Entry Age: Under 25 & $\begin{array}{c}0.002 \\
(0.008)\end{array}$ & $\begin{array}{l}-0.038 \\
(0.025)\end{array}$ \\
\hline Entry Age: 30 - 34 & $\begin{array}{c}0.006 \\
(0.008)\end{array}$ & $\begin{array}{l}-0.028 \\
(0.025)\end{array}$ \\
\hline Entry Age: 35 - 39 & $\begin{array}{c}0.001 \\
(0.009)\end{array}$ & $\begin{array}{l}-0.032 \\
(0.029)\end{array}$ \\
\hline Entry Age: 40 - 44 & $\begin{array}{c}0.036 * * * \\
(0.011)\end{array}$ & $\begin{array}{c}0.044 \\
(0.034)\end{array}$ \\
\hline Entry Age: 45 and Above & $\begin{array}{l}0.032 * * * \\
(0.009)\end{array}$ & $\begin{array}{c}0.041 \\
(0.026)\end{array}$ \\
\hline Male & $\begin{array}{l}-0.005 \\
(0.006)\end{array}$ & $\begin{array}{c}-0.043 * * \\
(0.017)\end{array}$ \\
\hline Salary in plan choice year $(\$ 000)$ & $\begin{array}{l}0.019 * * * \\
(0.004)\end{array}$ & $\begin{array}{l}0.042 * * * \\
(0.013)\end{array}$ \\
\hline Salary $^{2}$ & $\begin{array}{c}-0.001 * * * \\
(0.000)\end{array}$ & $\begin{array}{l}-0.002 * * \\
(0.001)\end{array}$ \\
\hline Employer: Higher Education & $\begin{array}{c}-0.222 * * * \\
(0.011)\end{array}$ & \\
\hline Employer: Local Government & $\begin{array}{l}-0.014 \\
(0.011)\end{array}$ & \\
\hline Employer: Public Education & $\begin{array}{c}-0.232 * * * \\
(0.009)\end{array}$ & \\
\hline System: Public Safety \& Firefighters & $\begin{array}{c}0.015 \\
(0.011) \\
\end{array}$ & $\begin{array}{c}0.012 \\
(0.030)\end{array}$ \\
\hline Observations & 16,095 & 2,711 \\
\hline Log likelihood & -5839.755 & -1431.432 \\
\hline Pseudo R-squared & 0.236 & 0.209 \\
\hline Mean & 0.182 & 0.388 \\
\hline
\end{tabular}

$* * * \mathrm{p}<0.01, * * \mathrm{p}<0.05, * \mathrm{p}<0.1$

Constant term and plan choice year also included. Reference categories: Plan Choice Defaulted into Hybrid; Entry Age 25-29; Employer State Government; System Public Employees; Choice Year 2012. 
Appendix Table 5. Probit Estimates of Second-Year Retention: Marginal Effects (standard errors in parentheses)

\begin{tabular}{|c|c|c|c|}
\hline \multirow[b]{2}{*}{ Independent Variable } & \multicolumn{3}{|c|}{ Dependent Variable: Remain in second year } \\
\hline & $\begin{array}{c}\text { Post-Reform } \\
\text { (1) }\end{array}$ & $\begin{array}{l}\text { All } \\
(2)\end{array}$ & $\begin{array}{c}\text { Hired } 7 / 2010- \\
6 / 2012 \\
(3)\end{array}$ \\
\hline Plan Choice: Chose DC & $\begin{array}{c}0.021 * * \\
(0.010)\end{array}$ & & \\
\hline Plan Choice: Chose Hybrid & $\begin{array}{c}0.084 * * * \\
(0.009)\end{array}$ & & \\
\hline Post-Reform & & $\begin{array}{c}-0.035 * * * \\
(0.004)\end{array}$ & $\begin{array}{c}-0.027 * * * \\
(0.006)\end{array}$ \\
\hline Entry Age: Under 25 & $\begin{array}{c}-0.029 * * * \\
(0.011)\end{array}$ & $\begin{array}{c}-0.027 * * * \\
(0.005)\end{array}$ & $\begin{array}{c}-0.025^{* *} \\
(0.010)\end{array}$ \\
\hline Entry Age: 30 - 34 & $\begin{array}{l}-0.004 \\
(0.013)\end{array}$ & $\begin{array}{c}0.019 * * * \\
(0.005)\end{array}$ & $\begin{array}{c}0.022 * * \\
(0.011)\end{array}$ \\
\hline Entry Age: 35 - 39 & $\begin{array}{l}0.026^{*} \\
(0.014)\end{array}$ & $\begin{array}{c}0.043 * * * \\
(0.006)\end{array}$ & $\begin{array}{c}0.039 * * * \\
(0.011)\end{array}$ \\
\hline Entry Age: 40 - 44 & $\begin{array}{c}0.042 * * * \\
(0.014)\end{array}$ & $\begin{array}{c}0.059 * * * \\
(0.006)\end{array}$ & $\begin{array}{c}0.077 * * * \\
(0.011)\end{array}$ \\
\hline Entry Age: 45 and Above & $\begin{array}{c}0.045 * * * \\
(0.012)\end{array}$ & $\begin{array}{c}0.054 * * * \\
(0.005)\end{array}$ & $\begin{array}{c}0.056 * * * \\
(0.010)\end{array}$ \\
\hline Male & $\begin{array}{c}0.017 * * \\
(0.008)\end{array}$ & $\begin{array}{c}0.017 * * * \\
(0.003)\end{array}$ & $\begin{array}{l}0.012 * \\
(0.007)\end{array}$ \\
\hline Salary in plan choice year $(\$ 000)$ & $\begin{array}{c}0.037 * * * \\
(0.003)\end{array}$ & $\begin{array}{c}0.025 * * * \\
(0.001)\end{array}$ & $\begin{array}{c}0.034 * * * \\
(0.003)\end{array}$ \\
\hline Employer: Higher Education & $\begin{array}{c}0.008 \\
(0.017)\end{array}$ & $\begin{array}{c}-0.030 * * * \\
(0.007)\end{array}$ & $\begin{array}{c}-0.030 * * \\
(0.013)\end{array}$ \\
\hline Employer: Local Government & $\begin{array}{c}0.069 * * * \\
(0.014)\end{array}$ & $\begin{array}{c}0.027 * * * \\
(0.005)\end{array}$ & $\begin{array}{c}0.039 * * * \\
(0.011)\end{array}$ \\
\hline Employer: Public Education & $\begin{array}{c}0.057 * * * \\
(0.013)\end{array}$ & $\begin{array}{c}0.029 * * * \\
(0.005)\end{array}$ & $\begin{array}{c}0.041 * * * \\
(0.010)\end{array}$ \\
\hline System: Public Safety \& Firefighters & $\begin{array}{c}0.128 * * * \\
(0.013)\end{array}$ & $\begin{array}{c}0.093 * * * \\
(0.005)\end{array}$ & $\begin{array}{c}0.103 * * * \\
(0.009)\end{array}$ \\
\hline Plan Choice Year: 2013 & $\begin{array}{c}-0.027 * * * \\
(0.008)\end{array}$ & & \\
\hline Plan Choice Year: 2014 & $\begin{array}{c}-0.169 * * * \\
(0.064)\end{array}$ & & \\
\hline Observations & 9,721 & 47,899 & 12,140 \\
\hline Log likelihood & -4220.202 & -18429.189 & -4821.414 \\
\hline Pseudo R-squared & 0.055 & 0.042 & 0.053 \\
\hline Mean & 0.828 & 0.862 & 0.852 \\
\hline
\end{tabular}

